\title{
O FIEL DA BALANÇA \\ O PAPEL DO PARLAMENTO BRASILEIRO NOS \\ DESDOBRAMENTOS DO GOLPE DE 1831 NO GRÃO-PARÁ*
}

\author{
André Roberto de A. Machado \\ Universidade Federal de São Paulo
}

\section{Resumo}

Nesse artigo pretende-se demonstrar que o Parlamento foi uma peça central para os desdobramentos políticos no Pará após o golpe que depôs o visconde de Goiana da presidência da província, em agosto de 1831. Será destacada também a atuação dos representantes paraenses em torno dessa questão, na Câmara e no Senado, defendendo as óticas das partes envolvidas, propondo punições ou anistias.

\section{Palavras-chave}

Pará • representação política • Império do Brasil.

\section{Correspondência}

Universidade Federal de São Paulo - Campus Guarulhos

Estrada do Caminho Velho, 333

Guarulhos - São Paulo - Brasil

CEP 07252-312

E-mail: andre.machado@unifesp.br

* Agradeço à Fapesp pelo financiamento da pesquisa. 


\title{
THE POINT OF BALANCE \\ THE BRAZILIAN PARLIAMENT'S PART IN THE DEVELOPMENT OF THE 1831'S COUP D'ÉTAT IN GRÃO-PARÁ*
}

\author{
André Roberto de A. Machado \\ Universidade Federal de São Paulo
}

\begin{abstract}
In this article I intend to demonstrate that the Parliament had an important role in the political development in Pará after of the coup d'état which deposed visconde de Goiana as president of the province, on August 1831. In this article it will be accentuated the performance of the elected representatives by Pará about this question in Camera and in Senate, defending the point of view of the involved parts, proposing punishments or amnesties.
\end{abstract}

\section{Keywords}

Pará • political representation • Empire of Brazil

\section{Contact}

Universidade Federal de São Paulo - Campus Guarulhos.

Estrada do Caminho Velho, 333

Guarulhos - São Paulo - São Paulo - Brazil

CEP 07252-312

E-mail: andre.machado@unifesp.br

* I thank Fapesp for the research support. 
No dia 7 de agosto de 1831, em Belém, a reunião do Conselho Presidencial foi interrompida abruptamente. O comandante de Armas, coronel Bittencourt, acompanhado por chefes de corpos militares da capital, entrou na sala das sessões e anunciou que, por vontade da tropa, vinha depor o visconde de Goiana do cargo de presidente do Grão-Pará. Nomeado pela Corte e exercendo a função na província há menos de 20 dias, o visconde de Goiana esboçou uma reação tímida, quase protocolar. Não havia qualquer condição para resistência, uma vez que o Palácio estava cercado por tropas.

$\mathrm{Na}$ condição de membro mais votado do Conselho Presidencial, o cônego Batista Campos era o sucessor legal do visconde de Goiana. Contudo, a presidência da província também não passaria para suas mãos, já que, momentos antes da deposição de Goiana, outro grupo armado havia detido o vice-presidente. Não só Batista Campos como vários outros homens acusados de estarem alinhados ao seu partido $^{1}$ estavam sendo presos em vários pontos de Belém ao mesmo tempo. No dia 10 de setembro de 1831, uma embarcação seguiu com o visconde de Goiana para o Rio de Janeiro, enquanto uma escuna levava, deportados para pontos ermos da província, Batista Campos e alguns dos seus aliados que não conseguiram fugir da caçada empregada contra eles a partir do dia 7 de agosto. ${ }^{2}$

Não só por sua ocorrência, mas especialmente pelos seus desdobramentos, o golpe de 1831 foi um marco no aprendizado político dos partidos paraenses após o alinhamento da província ao Império do Brasil. Após os revezes sofridos pelos grupos que aspiravam a subversão da ordem durante a guerra civil de 1823 e $1824,{ }^{3}$ apesar da ocorrência de alguns levantes armados, no período imediatamente anterior ao golpe era crescente a canalização das disputas políticas na província para os canais institucionalizados. Os paraenses já tinham eleito deputados para duas legislaturas, trocando dois terços da sua representação na Câmara de um pleito para o outro. Além do Conselho Presidencial, o Conselho Geral da Província já estava situado como uma das principais instituições do Pará, mesmo com pouco tempo de funcionamento. Neste Conselho, a composição heterogênea dos seus membros permitiu o debate em torno de temas que feriam interesses econômi-

1 Como se verá, a palavra "partido" era usualmente utilizada pelos próprios personagens destes eventos para designar os grupos políticos do Pará.

2 Uma boa narrativa desses eventos, com a transcrição de vários documentos, pode ser encontrada em RAIOL, Domingos Antonio. Motins políticos ou história dos principais acontecimentos políticos da provincia do Pará desde o ano de 1821 até 1835. Belém: UFPA, 1970, p. 213-231.

3 MACHADO, André Roberto de A. A quebra da mola real das sociedades: a crise política do Antigo Regime português na província do Grão-Pará (1821-25). São Paulo: Hucitec/Fapesp, especialmente a parte II. 
cos e políticos, assim como ressaltaram a representação de grupos resistentes a mudanças. Da mesma forma, lentamente instalavam-se transformações na justiça com a instituição dos juízes de paz e o fim do Tribunal de Justiça Militar, denunciado como instrumento de despotismo dos presidentes. ${ }^{4}$ Dessa forma, para além das suas implicações imediatas, a importância do golpe de 1831 está no fato de que este acontecimento pôs em xeque a capacidade das instituições manterem os conflitos políticos no Pará dentro dos limites impostos pela legislação.

Por isso, não é surpreendente que a lei e a legalidade passassem a estar no centro dos discursos políticos no Pará após a "Agostada" e que, nesse contexto, o Parlamento instalado no Rio de Janeiro subisse ao primeiro plano. Como será demonstrado, em várias ocasiões os "representantes da nação" foram chamados a ocupar o papel de "fiel da balança", a arbitrar o justo e impor duras sanções para aqueles que desrespeitassem o ordenamento legal. Se isto valeu para aqueles que sofreram a deportação para partes longínquas da província com o golpe, também valerá anos depois para os executores da "Agostada" que reclamarão estar sendo perseguidos judicialmente por seus adversários que desejavam vingança. Fica claro que, entre todas as instituições do Império, o Parlamento é encarado como uma espécie de "guardião" da observância das leis e dos direitos dos povos. ${ }^{5}$

Ao longo deste texto, buscar-se-á demonstrar que o Parlamento ocupou um espaço nas disputas políticas do Pará, decorrentes do golpe de 1831, de três maneiras: a primeira delas foi através dos parlamentares eleitos pelos paraenses que propuseram punições, anistias e representaram as diferentes óticas dos envolvidos nessa disputa. A segunda forma foi através do envio de várias representações, através das quais a sociedade da província, seja através das câmaras municipais, de abaixo assinados ou de pedidos individuais, exprimia seus pleitos diretamente à "Assembleia Geral". Aúltima forma foi através da imprensa. Ao longo da primeira metade da década de 1830, na guerra entre os jornais paraenses, o Parlamento e os ministérios foram chamados a tomar uma posição no conflito, assim como, em mais de uma ocasião, os partidos locais buscaram identificar seus procedimentos como semelhantes aos grupos que travavam disputas no Rio de Janeiro.

4 MACHADO,André Roberto deA. Redesenhando caminhos: o papel dos representantes do Grão-Pará na primeira legislatura do Império do Brasil (1826-29). Almanack Braziliense. São Paulo, n. 10, 2009.

5 De certa forma, ao analisar petições e representações, Vantuil Pereira demonstrou que essa imagem do Parlamento era compartilhada em todo Império. Além dos seus atributos políticos, talvez contribuísse para isso o fato do Parlamento apreciar nessa época matérias que hoje pertencem ao Judiciário. Ver PEREIRA, Vantuil. Ao soberano Congresso: petições, requerimentos, representações e queixas à Câmara dos Deputados e ao Senado. Os direitos do cidadão na formação do Estado imperial brasileiro (1822-31). Tese de doutorado. Niterói: UFF, 2008, p. 213-305. 
Todas essas manifestações deixavam clara a importância do Parlamento para o desfecho da disputa acirrada com a "Agostada", algo fartamente reconhecido pelos protagonistas destes eventos.

Contudo, antes de discutir o papel do Parlamento nos desdobramentos do golpe de 7 de agosto de 1831, as próximas páginas serão dedicadas a esclarecer quais são os enquadramentos a partir dos quais os episódios destacados estão sendo observados.

\section{Enquadramentos}

O golpe que depôs o visconde de Goiana da presidência do Pará está entre os episódios mais revisitados entre os historiadores que se debruçaram sobre as décadas de 1820 e 1830 na província, sobretudo aqueles que estavam ocupados com a Cabanagem. Isso se deve, sobretudo, à força interpretativa que ainda goza o livro Motins políticos, escrito por Domingos Antonio Raiol na segunda metade do XIX. ${ }^{6}$ A crítica feroz à obra de Raiol, acusada impiedosamente de conservadora, acompanha praticamente todas as tentativas dos jovens historiadores de erguer novos estudos sobre a Cabanagem. As críticas, no entanto, poucas vezes conseguiram superar algumas matrizes estabelecidas por Raiol que enquadram nosso entendimento sobre essas décadas. ${ }^{7}$

Uma dessas matrizes é a cronologia estabelecida no Motins políticos. Prova da grande inventividade e do talento incomum como historiador dentro dos cânones do XIX, Raiol viu uma unidade no período que vai da adesão do Pará às Cortes de Lisboa, em 1821, até a repressão da Cabanagem, em 1840. Ao contrário da quase totalidade dos historiadores de outras províncias que relegaram as ditas "revoltas regenciais" a um espasmo de violência, Raiol destacou o conflito como a marca do constitucionalismo, da independência e dos anos iniciais do Império no Pará.

6 RAIOL, Domingos Antonio. Motins políticos, op. cit. Para uma crítica à obra de Raiol e um balanço da historiografia da Cabanagem, veja de RICCI, Magda. Do sentido aos significados da Cabanagem: percursos historiográficos. Anais do Arquivo Público do Pará. Belém: s.i., 2001; PINHEIRO, Luís Balkar Sá Peixoto. Nos subterrâneos da revolta: trajetórias, lutas e tensões na Cabanagem. Tese de doutorado. São Paulo: PUC, 1998, cap. 1; LIMA, Leandro Mahalem de. Rios vermelhos: Perspectivas e posições de sujeito em torno da noção de Cabano na Amazônia em meados de 1835. Dissertação de mestrado. São Paulo: USP, 2008, cap. 1. Disponível em www.teses.usp.br.

7 Entre as análises que tiveram relativo sucesso em explorar a Cabanagem sob novos focos, podem ser citados de LIMA, Ana Renata do Rosário de. Revoltas camponesas no vale do Acará. Dissertação de mestrado. Pará (1822-40). Belém: UFPA/Naea, 2002; e de RICCI, Magda. Um morto, muitas mortes. A imolação de Lobo de Souza e as narrativas da eclosão cabana. In: NEVES, Fernando Arthur de Freitas; LIMA, Maria Roseane Pinto (org.). Faces da história da Amazônia. Belém: Pakatatu, 2006, p. 519-544. 
Se esta cronologia estabelecida por Raiol lhe deu o grande mérito de ter superado o círculo de giz dos historiadores coevos, que construíram a mítica narrativa do Império como um tempo de paz pontuado por conflitos isolados, por outro lado, criou uma camisa de força para muitos dos seus sucessores que passaram a ver os episódios no Pará, entre as décadas de 1820 e 1830, como alvo de interesse apenas na medida em que eram "causas" da Cabanagem. É sob esta ótica que está consagrada a análise do golpe de 1831 que depôs o visconde de Goiana da presidência do Pará: de forma bastante simplificada, ela seria um ponto de acirramento nas disputas que começaram no período da independência entre o grupo político liderado por Batista Campos, acusado por seus opositores de defender ideias radicais e incitar as ditas "classes ínfimas", e facções conservadoras que chegam a 1831 tendo como seu mais destacado líder Marcos Antonio Rodrigues Martins, personagem que nos anos anteriores estava do outro lado contenda. Como se verá, os golpistas justificaram a ação extrema, através da imprensa e de cartas à Corte, sob a alegação de que o visconde de Goiana favorecia o partido do cônego Campos e a anarquia, versão que o presidente deposto sempre negou, acrescentando a acusação de que seus algozes seriam restauradores. Abaixo, essas óticas serão confrontadas e problematizadas, mas agora o importante é ressaltar que a deposição de Goiana é um episódio crucial para o entendimento da Cabanagem dentro da interpretação consagrada por Raiol, já que para ele este conflito era fundamentalmente resultado da acumulação de disputas internas da província desde 1821, tendo pouca relevância a política fora das fronteiras do Pará. Resume bem a permanência dessa tese, a análise final que Pasquale Di Paolo faria do golpe de 1831, escrevendo cem anos depois de Raiol: para ele, "a revolução dos homens vindos das cabanas não surgiu improvisadamente: alimentava-se do arbítrio praticado, sem trégua, por parte do grupo dominante".

No entanto, é outro o enquadramento que este artigo propõe. O que se deseja compreender é qual a relação entre a política na Corte e as disputas na província, trazendo para o primeiro plano da análise o sistema representativo. Como adiantado na introdução, a deposição do visconde de Goiana e, sobretudo, os desdobramentos deste ato são revisitados aqui porque demonstram que, para a sobrevivência dos grupos políticos paraenses, era importante garantir alguma influência no Parlamento, já que decisões tomadas ali desequilibravam a correlação de forças locais. Da mesma forma, os paraenses estavam inse-

PAOLO, Pasquale di. Cabanagem: a revolução popular da Amazônia. $2^{\mathrm{a}}$ edição, Belém: Cejup, 1986, p. 126. Entre outros autores, esta ótica também pode ser encontrada no popular livro de Julio Chiavenato. Veja CHIAVENATO, Julio José. Cabanagem, o povo no poder. São Paulo: Brasiliense, 1984. 
ridos nos debates travados na Câmara e no Senado através de uma imprensa vigorosa, que não só julgava a atuação dos parlamentares como se punha na linha de frente dos que pretendiam influir na reorganização do Estado imperial após a abdicação. Como se verá abaixo, é um equívoco reduzir os conflitos entre os grupos políticos no Pará apenas a questões domésticas, como a disputa por cargos. Ainda que isto também seja um dos componentes das disputas, muitas divergências são iluminadas pelos grandes debates nacionais.

Nesse sentido, não é por acaso que uma das maiores rupturas institucionais da província aconteceu logo após a abdicação de d. Pedro I. A queda do imperador abriu caminho para uma radicalização política que, assim como no período da independência, dissolveu os parâmetros da vida política. ${ }^{9}$ No Rio de Janeiro, parlamentares como o deputado Paula Souza bradavam que a Constituição em vigência era a imposição de um déspota, à ponta de baionetas. ${ }^{10}$ Antes das reformas do Ato Adicional, ainda na Câmara encampam-se debates exaltados, como a anulação de todos os títulos nobiliárquicos concedidos pelo ex-imperador, ou mesmo a permissão para que as províncias tivessem constituições particulares. ${ }^{11}$ Na imprensa, os limites eram ainda mais elásticos. Na Corte, Emília Viotti da Costa lembra que o jornal Nova Luz Brasileira defendia, entre outras coisas, a eleição para todos os cargos, inclusive o de monarca. ${ }^{12} \mathrm{Na}$ Bahia, ao fazer uma análise da Revolução Francesa, o jornal O Democrata dizia que ela ainda não tinha acabado e que só teria fim quando os reis tivessem exterminado os povos ou quando os povos tivessem dado cabo dos reis. ${ }^{13} \mathrm{O}$ outro lado da moeda foi o crescimento de um discurso que via, em qualquer sugestão de reforma, a ameaça de uma revolução ou, ainda, a via que pregava mudanças pontuais para evitar a radicalização.

Os exemplos de radicalismos ocorridos em outras partes do país foram rapidamente usados no Pará para respaldar as ações das facções. Como se verá, a abdicação foi a senha para que os partidários de Batista Campos pressionassem por reformas, exigindo também a deposição do governador de armas sob alegação de que, em outras províncias, os absolutistas estavam caindo. Do outro lado, a posterior depo-

9 Sobre essa questão, para a independência, veja de MACHADO, André Roberto de A. A quebra da mola real das sociedades, op. cit., cap. 3.

${ }^{10}$ Anais do Parlamento Brasileiro. Câmara dos senhores deputados. Sessão de 1831. Rio de Janeiro: Tipografia de H. J. Pinto, 1878. [APB (1831)], em 20 de maio.

${ }^{11}$ APB (1831), em 20 de junho e 12 de outubro.

${ }^{12}$ COSTA, Emília Viotti da. Liberalismo: teoria e prática. In: Idem. Da monarquia à república: momentos decisivos. $7^{\text {a }}$ edição. São Paulo: Unesp, 1999, p. 149-150.

${ }^{13}$ FONSECA, Silvia. Federação e república na imprensa baiana (1831-36). In: LESSA, Mônica L.; FONSECA, Silvia C. P. de B. Entre a monarquia e a república: imprensa, pensamento politico e historiografia (1822-89). Rio de Janeiro: Eduerj, 2008. A edição citada é de 1834. 
sição de Goiana foi justificada pelos golpistas como o alinhamento da província ao movimento de moderação que tomava o país para rechaçar o carro da revolução.

As evidências sobre a importância do Parlamento na vida política do Pará superaram, inclusive, as expectativas iniciais da pesquisa, uma vez que se tinha em conta as enormes dificuldades de comunicação do Pará com o sul do continente que lhe conferiam um aparente isolamento. É amplamente conhecido pela historiografia que, no período da independência, os contemporâneos acreditavam que a maior facilidade de transporte entre o Pará, Maranhão e a Europa tornavam pouco provável a integração dessas províncias ao Império do Brasil, percepção que chegou a ser abertamente expressa na constituinte de $1823 .{ }^{14} \mathrm{Em} 1828$, das embarcações que chegaram a Belém, excetuando as 26 vindas do Maranhão, apenas uma tinha procedência de portos brasileiros, enquanto 31 ainda tinham origem em Portugal. ${ }^{15} \mathrm{Na}$ década de 1830 , uma viagem de Belém a Corte levava em torno de três meses e deputados queixavam-se que respostas e notícias oficiais chegavam a levar mais de um ano para serem recebidas. ${ }^{16}$ Mesmo com as incontestes dificuldades de integração do Pará ao centro do poder do Império do Brasil, algumas vezes manifestada na dificuldade de fazer cumprir decisões da Corte, o Parlamento estava continuamente no centro da disputa dos grupos políticos paraenses, seja através da imprensa, das eleições, do envio de petições ou da disputa por cargos como o Conselho Geral de Província, órgão que tinha interlocução com a Câmara e o Senado.

Contudo, antes de discutir o papel do Parlamento nos desdobramentos do golpe de 7 de agosto de 1831, nas próximas páginas serão exploradas as razões do conflito que culminou com a deposição do visconde de Goiana da presidência do Grão-Pará. Isso dará melhores contornos às disputas na província e ajudará a entender como posteriormente cada grupo apelará ao Parlamento.

${ }^{14}$ MACHADO, André Roberto de A. A quebra da mola real das sociedades, op. cit., cap. 2. COELHO, Geraldo Mártires. Onde fica a Corte do senhor imperador? In: JANCSÓ, István (org.). Brasil: formação do Estado e da nação. São Paulo - Ijuí: Hucitec/Fapesp/Unijui, 2003. Sobre a dúvida da integração do Pará e Maranhão no Império do Brasil durante a constituinte de 1823, veja de RODRIGUES, José Honório. A Assembleia Constituinte de 1823. Petrópolis: Vozes, 1974, p. 113-117.

${ }^{15}$ SILVA, Ignácio Accioli de Cerqueira e. Corografia paraense ou descrição física, histórica e política da província do Grão-Pará. Salvador: Typografia do Diário, 1833, p 154. A tabela completa também está transcrita em PINHEIRO, Luís Balkar Sá Peixoto. Nos subterrâneos da revolta, op. cit., p. 180.

${ }^{16}$ Anais do Parlamento Brasileiro. Câmara dos senhores deputados. Sessão de 1830. Rio de Janeiro: Tipografia de H. J. Pinto, 1878. [APB (1830)], em 8 de julho. 


\section{As motivações para o golpe de 7 de agosto}

José Maria da Silva Bittencourt, então coronel e comandante de Armas do Pará, apesar de ter ocupado um papel menor na narrativa feita por Raiol sobre a deposição do visconde de Goiana e depois quase desaparecer das páginas do clássico Motins políticos, foi constantemente citado nos anos seguintes pelos periódicos editados por Batista Campos e seus aliados. Nesses jornais, Bittencourt não só era descrito como um dos líderes do golpe militar, como era acusado até de ter enriquecido com a Agostada. ${ }^{17}$ Além disso, esses periódicos deixam claro que a presença desse militar na vida política da província não se extinguiu com a sua baixa da função de comandante de Armas, em fevereiro de 1832. Ainda entre o final deste ano e o começo de 1833, Bittencourt era um fantasma para essa facção paraense que utilizou suas folhas para divulgar a ideia de que ele não podia receber votos para deputado por estar pronunciado em processos judiciais. ${ }^{18}$ Apesar da forte campanha contrária, sobretudo de Batista Campos nas folhas do Publicador Amazoniense, Bittencourt conseguiu votos suficientes para alcançar a posição de suplente na terceira legislatura pelo Pará, cargo que jamais ocupou. ${ }^{19}$

Em 1864, o próprio Bittencourt escreveu um longo texto em que expunha sua ótica sobre o período entre 1831 e 1836 no Pará. Extremamente minuciosa, a narrativa não poupa detalhes para construir os perfis com os quais o excomandante de Armas desejava fixar a imagem dos seus adversários. Exemplo disso é o fato de muitas páginas serem escritas apenas para contar a viagem que o trouxe juntamente com o visconde de Goiana ao Pará. Nela a mútua antipatia é imediata. Goiana é descrito como um gordo sem movimentos, beirando ao patético, enquanto Bittencourt era a figura do bravo soldado. Das várias cenas descritas para corroborar esta imagem, tem grande destaque a narrativa da descida de Goiana em Pernambuco, por conta do visconde ter solicitado para o

\footnotetext{
${ }^{17}$ Instituto Histórico e Geográfico Brasileiro [IHGB] - PER 32.14 - O Publicador Amazoniense. Edição de 12 de janeiro de 1833; IHGB - PER 33.20 - O Paraguassu. Edição de 1 de março de 1833. Além de reunir a coleção de jornais paraenses hoje sob a guarda do IHGB, Manuel Barata também fez uma lista em que identificava quem eram os editores dos periódicos, algo nem sempre tão claro. Veja de BARATA, Manuel. Formação histórica do Pará. Belém: UFPA, 1973. Em junho de 1831, circulou um impresso, que Manuel Barata creditava a Batista Campos, que também listava os jornais existentes no Pará e os seus editores. IHGB - 115,6,17 - Carta aos cidadãos paraenses, verdadeiros independentes, amigos da liberdade, residentes nesta cidade e no interior da província. Carta n. 02.

${ }^{18}$ IHGB - PER 32.14 - O Publicador Amazoniense. Edição de 15 de dezembro de 1832.

${ }^{19}$ IHGB - PER 32.14 - O Publicador Amazoniense. Edição de 4 de fevereiro de 1833; IHGB 1,3,12 - Apontamentos relativos aos acontecimentos do Pará, de 1831 a 1836, que lhe oferece o seu amigo, o general José Maria da Silva Bittencourt (Cópia feita para Manuel Barata de documento da seção de manuscritos da Biblioteca Nacional - RJ).
} 
seu desembarque o uso de cadeiras geralmente destinadas às mulheres, o que, supostamente, seria prova da sua falta de virilidade. O interessante na construção narrativa de Bittencourt é que cada evento só é descrito para corroborar a ideia que ele já possuía antes do embarque: o coronel tinha certeza de que não poderia afinar-se com o visconde de Goiana por saber que ele tinha, em suas palavras, "ideias liberais". ${ }^{20}$ Nesse sentido, chama a atenção o fato de constar na ata do Conselho Presidencial de 7 de agosto de 1831 que o comandante de Armas justificou a deposição de Goiana pelo fato do presidente ter se "manifestado a favor do partido liberal" que existia na província. ${ }^{21}$

Escrito quase três décadas após os acontecimentos, o relato de Bittencourt repisava, em linhas gerais, as mesmas justificativas para a deposição de Goiana que foram dadas à época pelos jornais controlados pelos executores do golpe, assim como nos documentos oficiais produzidos por eles e enviados para o Rio de Janeiro. Até mesmo a denominação de "partido liberal", utilizada por Bittencourt à época, foi substituída no seu relato por "ultra-liberais" para definir Batista Campos e seus aliados, uma vez que o grupo paraense que derrubou o visconde de Goiana iria reivindicar para si a condição de liberais, mas "moderados". Uma das folhas desses ditos "moderados", o jornal A Opinião, controlado por Marcos Antonio Rodrigues Martins e seus aliados, em um suplemento e na edição do dia 24 de agosto, alegava que a deposição de Goiana era o último recurso para evitar a subversão da ordem na província já que, na sua versão, o presidente arquitetava entregar seu cargo a Batista Campos sob o pretexto de estar doente. Um passo decisivo de Goiana nessa direção seria dado, segundo o jornal, justamente no dia 7 de agosto, quando o presidente deveria propor ao seu conselho o fim do corpo armado de voluntários, impropriamente chamado pelo periódico de Guarda Nacional, liderado por Marco Antonio Rodrigues Martins, um conhecido opositor de Batista Campos. ${ }^{22}$ É em nome da ordem e da liberdade que o golpe não só é justificado como comparado à abdicação de d. Pedro I:

${ }^{20}$ IHGB - 1,3,12 - Apontamentos relativos aos acontecimentos do Pará, de 1831 a 1836, que lhe oferece o seu amigo, o general José Maria da Silva Bittencourt. O ressentimento em relação àqueles que considera como "liberais" percorre todo o texto. Bittencourt considerava que sua nomeação para o cargo em uma província tão distante era uma espécie de punição ou prevenção daqueles que o consideravam muito ligado ao ex-imperador, especialmente depois dele ter se negado a retirar suas condecorações dadas pelo governo anterior.

${ }^{21}$ Ata do Conselho Presidencial de 7 de agosto de 1831, transcrita em RAIOL, Domingos Antonio. Motins políticos, op. cit., p. 215-216.

${ }^{22}$ IHGB - PER 32.13 - A Opinião. Suplemento n. 18 (sem data) e edição de 24 de agosto de 1831. 
O Povo e a Tropa do Pará oferece a todas as demais províncias do Império este enérgico exemplo do seu esforço e espera que elas o saberão imitar quando algum de seus (ilegível) mandões ousar aliar-se com inimigos da Liberdade e de sua paz intestina. O Direito Natural que escudou os fluminenses em 7 de abril é o mesmo que defendeu os paraenses em 7 de agosto. ${ }^{23}$

Se em seus jornais, nos anos seguintes, Batista Campos recusou o rótulo de "moderados" aos seus adversários e acusou ser o desejo de restauração de d. Pedro I o motor da deposição do visconde de Goiana, por sua vez seus inimigos espalharam textos que o acusavam de um "pecado capital": segundo eles, Batista Campos estaria sublevando a "ínfima classe". A carta escrita para o Ministério do Império por Marcelino Cardoso, conselheiro que ocupou a presidência com a deposição de Goiana, tomava essa ideia como centro para descrever a luta política na província. Assim como fizeram os jornais dos executores do golpe e o relato escrito por Bittencourt trinta anos depois, a carta de Marcelino Cardoso ignorava as diversas aspirações na província ao reduzir a luta política, em suas palavras, a dois partidos: o primeiro seria formado pelo que ele chamava de "melhor gente" que sustentaria a "boa ordem", da qual a ação de 7 de agosto seria um exemplo. Na sequência, assim descreve seus opositores: "se é que partido pode se chamar, [é] composto de um punhado de indivíduos, quase todos de baixa condição, entre os quais se notavam alguns mulatos e pretos de má qualidade". ${ }^{24}$ Indo na mesma direção, o relato de Bittencourt apenas nomeia o que Marcelino Cardoso chamou de "melhor gente": empregados públicos, gente do comércio, pessoas abastadas e preponderantes que eram comandantes das tropas ou tinham influência sobre eles. Segundo o ex-comandante das Armas, esses homens viam no combate ao outro partido a defesa de uma causa própria, da manutenção das coisas como estavam e, por isso, tinham se tornado aliados dos governantes anteriores até serem, na versão dos golpistas, desprezados pelo visconde de Goiana. ${ }^{25}$ Será assinalado

${ }^{23}$ IHGB - PER 32.13 - A Opinião. Edição de 24 de agosto de 1831. A ortografia foi atualizada.

${ }^{24}$ Carta de Marcelino José Cardoso ao ministro dos Negócios do Império, em 9 de setembro de 1831. Transcrito em RAIOL, Domingos Antonio. Motins políticos, op. cit., p. 232-234. Além dos documentos já citados, outros impressos circularam posteriormente com a mesma linha argumentativa. Sobre isso, veja de LIMA, Leandro Mahalem de. Rios vermelhos, op. cit., cap. 3.

${ }^{25}$ IHGB - 1,3,12 - Apontamentos relativos aos acontecimentos do Pará, de 1831 a 1836, que lhe oferece o seu amigo, o general José Maria da Silva Bittencourt. A partidarização dos paraenses foi impulsionada, no começo da década de 1830, pela criação de sociedades políticas, fenômeno que estava espalhado em todo o Império. Para o impacto disso no Pará e a utilização dos jornais como veículos dessas sociedades, veja de SALLES, Vicente. Memorial da Cabanagem. Belém: Cejup, 1992, p. 46-83. Sobre a proliferação de sociedades políticas no Império no começo da década de 1830, veja de VERNET, Augustin. Sociedades políticas da província de São Paulo na primeira metade do periodo regencial. Tese de doutorado. São Paulo: USP, 1975. 
adiante que essa linha argumentativa teve impacto no Rio de Janeiro, sendo que mais de uma vez membros do Ministério e do Parlamento manifestaram sua preocupação em preservar os "homens de consideração" do Pará, mesmo que estes estivessem envolvidos na deposição de um presidente. Por sua vez, também será demonstrado que esta postura serviu para que jornais alinhados a Batista Campos acusassem o Parlamento e o Ministério de não garantir a aplicação igual para todos da lei, independentemente da posição social e da simpatia política.

Se o quadro pintado ao Ministério era o da "salvação da ordem" graças ao 7 de agosto, na província, a propaganda era ainda mais alarmista. No dia 25 de agosto, o presidente Marcelino Cardoso distribuía uma proclamação em que, além de negar que uma facção portuguesa tivesse assumido o poder, ainda acusava seus adversários de incentivarem a guerra civil e a revolução que eram responsáveis, segundo a proclamação, pela miséria, a fome e o "nada político" que afligia a América espanhola. ${ }^{26}$ Além disso, apesar de estar apenas sugerida na carta de Marcelino Cardoso ao Ministério, nas folhas que correram na província para justificar a Agostada, um dos principais pontos era a acusação de que Batista Campos era uma ameaça para a manutenção da escravidão africana, apesar de documentos e da bibliografia especializada demonstrarem fartamente que Batista Campos estava longe de ser um abolicionista. ${ }^{27}$ No jornal $A$ Opinião, dizia-se que "quatro ou cinco negros libertos foram iniciados em um mistério que tendia nada menos que a perfeita dissolução da ordem social no Brasil; e estes negros foram cridos apóstolos para catequizar seus irmãos cativos". ${ }^{28}$ Apesar da escravidão negra no Pará ter tido menor importância se comparada a outras províncias do Império, ela estava altamente concentrada: $60 \%$ dos cativos de origem africana viviam nas regiões de Belém e de Cametá, estimando-se que só a capital da província contasse com mais de cinco mil escravos. ${ }^{29}$ Apesar da província depender em maior escala do trabalho compulsório de indígenas, como se verá adiante, esse contingente de escravos africanos altamente concentrado em algumas regiões era

${ }^{26}$ IHGB - 105, 6, 23 - Coleção de proclamações, atas e outros impressos políticos relativos ao Pará entre 1827 e 1837. (Doc. 5 - Proclamação do presidente Marcelino José Cardoso em 25 de agosto de 1831).

${ }^{27}$ Veja, entre outros, SILVA, João Nei Eduardo. Batista Campos: uma discussão biográfica na historiografia paraense. In: BEZERRA NETO, José Maia; GUSMÁN, Décio de Alencar (org.). Terra matura: Historiografia \& história social na Amazônia. Belém: Paka-tatu, 2002, p. 139-149.

${ }^{28}$ IHGB - PER 32.13 - A Opinião. Suplemento n. 18 (sem data).

${ }^{29}$ Um debate sobre esta questão está em MACHADO, André Roberto de A. A quebra da mola real das sociedades, op. cit., cap. 2. Com outra perspectiva, sobre a escravidão negra no Pará, veja de BEZERRA NETO, José Maia. Escravidão negra no Grão-Pará (séculos XVIII-XIX). Belém: Pakatatu, s.d.; e de SALLES, Vicente. O negro no Pará, sob o regime da escravidão. Belém: UFPA, 1971. 
o suficiente para fazer valer a ideia de Cipriano Barata de que a ameaça de um levante de negros, ainda que falsa, era sempre útil para a repressão. ${ }^{30}$

$\mathrm{O}$ visconde de Goiana, no manifesto que publicou no jornal Farol Maranhense, manteve a defesa que exprimiu no momento da sua deposição, afirmando que não favoreceu nenhum grupo e que apenas cumpriu a Constituição. ${ }^{31}$ Excetuando a atribuição do golpe a uma facção desejosa da união do Pará a Portugal, acusação que Raiol claramente menosprezou, a narrativa construída em Motins políticos privilegiou a versão do visconde de Goiana para os acontecimentos. Neste relato, além da recusa em perseguir Batista Campos e da oposição ao corpo de voluntários liderado por Marco Martins, apareciam, no primeiro plano das razões para a sua deposição, os descontentamentos que, segundo o presidente, foram gerados por suas ações que visavam desmontar o que ele chamou de "servidão dos índios". Baseando-se, sobretudo, na narrativa de Raiol, Julio José Chiavenato ironizou o fato de que Marcelino Cardoso, em suas comunicações oficiais sobre a deposição de Goiana, não tenha tocado na questão da mão de obra indígena, o que significava esconder o que para este autor foi a principal razão do golpe. ${ }^{32}$ Contudo, se os executores do golpe não mencionaram isso como um das razões da Agostada, o silêncio sobre esta questão também foi quase completo por parte dos que sofreram o golpe. Excetuando o manifesto do visconde de Goiana, nessa pesquisa o único registro encontrado nessa linha está na edição de 12 de janeiro de 1833 do Publicador Amazoniense. Nesse número, Batista Campos acusava os antigos comandantes das Milícias de Ligeiros - corpo formado por indígenas - de serem um dos principais responsáveis pelo golpe por estarem descontentes com o fim do seu corpo. ${ }^{33}$ Além de ser o único registro, esta afirmação é bastante problemática, pois, como se verá, a notícia da decisão do Parlamento de dissolver as Milícias de Ligeiros do Pará chegará na província depois da Agostada.

\footnotetext{
${ }^{30}$ SOUZA FILHO, Argemiro Ribeiro de. Confrontos políticos e redes de sociabilidade: da crise do Antigo Regime à formação do Estado Nacional - Bahia. Relatório de Qualificação do doutorado. São Paulo: USP, 2009, p. 104-105. Thomas Flory mostra que o medo de uma rebelião negra foi constantemente usado contra os liberais e as propostas de reforma. FLORY, Thomas. El juez de paz y el jurado em el Brasil imperial: control social y estabilidade política en el nuevo estado. México: Fondo de Cultura Economica, 1986, cap. 2.

31 Manifesto do visconde de Goiana no jornal Farol Maranhense de 25 de outubro de 1831, transcrito em RAIOL, Domingos Antonio. Motins políticos, op. cit., p. 228-231.

${ }^{32}$ CHIAVENATO, Julio José. Cabanagem, o povo no poder. São Paulo: Brasiliense, 1984, p. 4647. Também se apoiando em Raiol, Pasquale Di Paolo atribui à disputa pelos índios a principal causa da Agostada. Veja PAOLO, Pasquale di. Cabanagem: a revolução popular na Amazônia. Belém: Cejup, 1986, cap. 3.

${ }^{33}$ IHGB - PER 32.14 - O Publicador Amazoniense. Edição de 12 de janeiro de 1833.
} 
Apesar do visconde de Goiana insistir na sua imparcialidade, a verdade é que algumas das suas políticas, ainda que de fato respaldadas na legislação, acabaram decidindo favoravelmente ao grupo de Batista Campos algumas disputas que vinham se arrastando há tempos na província. A questão da mão de obra dos indígenas é exemplar disso.

Como em outras matérias, a orientação geral da política indigenista em todo o Império estava sustentada pela legislação do período colonial. ${ }^{34}$ No caso do Pará, vigorava a lei de 1798 que acabou com o Diretório. ${ }^{35}$ Esta lei criou mudanças para os indígenas de modo geral, mas as que interessam especialmente a este estudo foram as que atingiram um grupo específico que aparece por diversas vezes na documentação, nomeado, por outros ou por eles mesmos, genericamente como tapuios. ${ }^{36}$ Os tapuios eram índios destribalizados que viviam entre os brancos distribuídos nas vilas, povoados e na cidade do Pará, constituindo-se ainda nesse período na maior fonte de mão de obra da região. ${ }^{37}$ Com diversos graus de

${ }^{34}$ Apenas em 1845 será aprovada uma legislação indigenista abarcando todo o Império do Brasil, o decreto 426 - "Regulamento acerca das missões de catequese e civilização dos índios". Essa questão deu margem para a famosa tese de Manuela Carneiro da Cunha, de que teria havido nesse período um "vácuo legislativo" sobre a questão indígena. Veja de CUNHA, Manuela Carneiro da (org.). Legislação indigenista no século XIX: uma compilação (1808-1889). São Paulo: Edusp / Comissão Pró-Índio de São Paulo, 1992. Contudo, na mesma direção que propõe esse artigo, vários historiadores têm mostrado que, a despeito da inexistência de uma legislação geral, a questão indígena sofreu mudanças ou manteve a orientação do período colonial por conta de políticas e legislações provinciais. Sobre isso veja de SPOSITO, Fernanda. Nem cidadãos, nem brasileiros: indígenas na formação do Estado nacional brasileiro e conflitos na província de São Paulo (1822-1845). Dissertação de mestrado. São Paulo: USP, 2006. Disponível em: www. usp.teses.br; de MONTEIRO, John. Entre o gabinete e o sertão: projetos civilizatórios, inclusão e exclusão dos índios no Brasil Imperial. In: Idem. Tupis, tapuias e historiadores: estudos de história indígena e indigenismo. Tese de livre docência. Campinas: Unicamp, 2001; e de SAMPAIO, Patrícia Melo. Política indigenista no Brasil imperial. In: GRINBERG, Keila; SALLES, Ricardo. História do Brasil imperial. 3 volumes. Rio de Janeiro: Civilização Brasileira, 2010.

${ }^{35}$ Patrícia Sampaio lembra que, ao contrário do Diretório, a aplicação da lei de 1798 ficou restrita ao Pará. Essa pesquisa também encontrou evidências nessa direção, como discussões no Parlamento a respeito do funcionamento do sistema do Diretório nas províncias. Veja de SAMPAIO, Patrícia Maria de Melo. Espelhos partidos: etnia, legislação e desigualdade na colônia. Sertões do Pará, 1755-1823. Tese de doutorado. Niterói: UFF, 2001, introdução.

${ }^{36}$ Dependendo do grau de incorporação ao mundo dos brancos, além de tapuios, esses indígenas ainda podiam ser chamados de índios civilizados ou caboclos. Ver FREIRE, Ribamar Bessa. Rio Babel: a história das línguas na Amazônia. Rio de Janeiro: Atlântica, 2004, cap. 4.

${ }^{37}$ Nos documentos encontrados, a "fome" por braços na província, durante as décadas de $1820 \mathrm{e}$ 1830, sempre se refere aos tapuios e não aos escravos africanos. Exemplo disso, é uma memória sobre a agricultura da província escrita pelo vereador de Óbidos, Martinho da Fonseca Seixas. Ele reclamava que a província não era mais rica porque, com a extinção do Diretório, os índios puderam sair das vilas e povoados onde estavam e voltar para as matas, o que produziu uma carência de mão de obra. Arquivo Público do Estado do Pará [APEP] - Caixa 35 - Série 13, doc. 157, de 10 de setembro de 1832. Em 1828, o recém-chegado presidente, barão de Bagé, fazia 
incorporação ao mundo dos brancos, se existiam tapuios sem ocupação fixa nem estabelecimento próprio, nas listas de presos durante a Cabanagem estão citados tapuios identificados com diversas profissões, inclusive como negociantes. ${ }^{38}$

A lei de 1798, além de garantir a condição de homens livres, extinguiu a tutela sobre esses indígenas que existiu durante o Diretório o que, na letra da lei, tornava-os iguais a qualquer súdito do monarca portuguêss. ${ }^{39}$ Contudo, essa mesma legislação que garantia a sua liberdade, sob o pretexto de evitar o ócio desses indivíduos, criou mecanismos para exploração compulsória da mão de obra dos tapuios. Além do trabalho em obras públicas, como no Pesqueiro e no Arsenal da Marinha, tapuios identificados pelos oficiais comandantes e pelos juízes como sem ocupação fixa, podiam ser obrigados a trabalhar para particulares se estes alegassem que não conseguiam contratar por salário alguém que os ajudasse a fazer a colheita ou servir de remador. Existiam rígidas regras para submeter esses indígenas ao trabalho compulsório, mas elas eram frequentemente burladas, uma vez que não havia escravos de origem africana em número suficiente para saciar a "fome" por braços na província. ${ }^{40} \mathrm{Na}$ verdade, os testemunhos da época descrevem onipresença dos tapuios em quase todas as atividades do Pará. Em seu livro de viagem, Spix e Martius relatavam com espanto que os indígenas, mesmo em Belém, realizavam as tarefas que em outras províncias eram feitas por escravos negros. ${ }^{41}$

Ao observar a legislação de 1798, percebe-se que os tapuios ficaram submetidos a uma disciplina militar, organizados em milícias. ${ }^{42}$ A grande participação desses indígenas nas milícias armadas e no exército foi registrada amplamente pelos contemporâneos e foi um ponto de instabilidade na província durante as

exatamente o mesmo diagnóstico. APEP - Códice 870, doc. 02, em 03 de junho de 1828.

${ }^{38}$ IHGB - Lata 290, pasta 3. Relação de presos enviados do Pará para a Corte (1836).

${ }^{39}$ Para compreender as diferenças entre o Diretório e a lei de 1798, veja de SAMPAIO, Patrícia Maria de Melo. Espelhos partidos, op. cit. Sobre o Diretório Pombalino, veja de DOMINGUES, Angela. Quando os índios eram vassalos: colonização e relações de poder no norte do Brasil na segunda metade do século XVIII. Lisboa: Comissão Nacional para as comemorações dos descobrimentos portugueses, 2000.

${ }^{40}$ Sobre os tapuios, a legislação de 1798 e as formas de trabalho compulsório, veja de MOREIRA NETO, Carlos de Araújo. Índios da Amazônia: de maioria a minoria (1750-1850). Petrópolis: Vozes, 1988; SAMPAIO, Patrícia Maria de Melo. Espelhos partidos, op. cit.; PRADO JR., Caio. Formação do Brasil Contemporâneo (Colônia). São Paulo: Brasiliense, 1972, p. 98-99. CLEARY, David. Lost altogether to the civilised world: race and Cabanagem in Northern Brazil, 1750 to 1850. Comparative studies in society and history. 1998; FREIRE, José Ribamar Bessa. Rio Babel, op. cit.; MACHADO, André Roberto de A. A quebra da mola real das sociedades, op. cit.

${ }^{41}$ SPIX, Johann Baptist; MARTIUS, Carl Friedrich Philipp. Viagem pelo Brasil: 1817-1820. Tradução de Lucia Furquim Lahmeyer. Belo Horizonte / São Paulo: Itatiaia / Edusp, 1981, p. 26-28.

${ }^{42}$ Entre outros, veja de SAMPAIO, Patrícia de Melo. Espelhos partidos, op. cit., cap. 11. 
décadas de 1820 e $1830 .{ }^{43}$ Além das milícias armadas, criou-se exclusivamente com tapuios a chamada "Milícia de Ligeiros", um corpo submetido a oficiais militares, no qual seus membros serviam, na maior parte do tempo, apenas como mão de obra para diversas atividades. Ainda na década de 1820, começou a disputa pelo controle desses braços. O presidente da província, barão de Bagé, escrevia, em 1828, uma carta ao ministro da Guerra em que dizia ser um absurdo que as Milícias de Ligeiros ficassem sob controle militar, que no topo da hierarquia tinha o comandante de Armas. ${ }^{44}$ Claramente, desejava trazer para o controle civil o comando desses braços. Tanto era assim que em uma carta ao ouvidor da Comarca do Rio Negro, o barão de Bagé lamentava não poder interferir no Corpo de Ligeiros e orientava o ouvidor para que buscasse controlar todos os índios que não estavam sob essa hierarquia, colocando-os para trabalhar e não permitindo que voltassem para as matas. Dizia que o desenvolvimento da província dependia do emprego desses braços. ${ }^{45}$

Quando o visconde de Goiana chegou ao Grão-Pará, as disputas em torno desse tema tinham subido de tom por conta dos embates entre as facções políticas em uma nova arena: o Conselho Geral da Província. ${ }^{46}$ No final de 1829, Batista Campos propôs neste Conselho uma resolução que pretendia extinguir os comandos militares dos distritos que, segundo ele, ao abusivamente ocupar funções de polícia, causavam "vexações" ao povo "descarregando neles um governo e mando puramente militar e absoluto". Em lugar disso, Campos pretendia que oficiais da segunda linha prestassem o serviço de polícia sob o comando dos juizes de

${ }^{43}$ Ignácio Accioli afirmava que o exército que conquistou Caiena foi formado majoritariamente por tapuios. Ver SILVA, Ignácio Accioli de Cerqueira e. Corografia paraense, op. cit., p. 114. Spix e Martius destacaram que os tapuios eram parte considerável da infantaria regular. SPIX, Johann Baptist; MARTIUS, Carl Friedrich Philipp. Viagem pelo Brasil, op. cit., p. 28 e 31-32. Ver também de NOGUEIRA, Shirley Maria Silva. Razões para desertar: institucionalização do exército no Estado do Grão-Pará no último quartel do século XVIII. Dissertação de mestrado. Belém: Naea / UFPA, 2000; e de MACHADO, André Roberto de A. A quebra da mola real das sociedades, op. cit.

${ }^{44}$ APEP - Códice 869, doc. 03, em 20 de maio de 1828.

${ }^{45}$ Carta do Barão de Bagé ao ouvidor da Comarca do Rio Negro em 19 de setembro de 1828, transcrita por REIS, Arthur Cezar. A autonomia do Amazonas. Manaus: Governo do Estado do Amazonas, 1965, p. 128-131.

${ }^{46}$ Existiam dois conselhos em cada província nesse período, ambos eleitos. O primeiro era o Conselho Presidencial, um corpo que o presidente reunia e que tinha poder de voto nas decisões do Poder Executivo da província. O segundo era o Conselho Geral da Província, que foi regulamentado pelo Parlamento durante a primeira legislatura. Os membros eleitos do Conselho Geral podiam propor resoluções para melhoramentos na província que, se aprovadas no Conselho, seguiam para o Parlamento no Rio de Janeiro. Apenas se fossem aprovadas por deputados e senadores estas resoluções viravam lei. Sobre estas questões, veja de SLEMIAN, Andréa. Sob o império das leis: Constituição e unidade nacional na formação do Brasil (1823-34). São Paulo: Hucitec / Fapesp, 2009, p. 148-185. 
paz. ${ }^{47}$ Ou seja, a proposta visava tirar o serviço de polícia do comando militar e passá-lo para o comando civil, uma demanda tipicamente liberal e um tema caro para o grupo de Batista Campos. Afinal, ainda durante o Vintismo, era Campos o editor do periódico $O$ Paraense quando este jornal se posicionou a favor da Junta Civil na disputa com o comandante de Armas pelo controle do poder de polícia. ${ }^{48}$ Da mesma forma, em 1830, o primeiro atrito de Batista Campos com o então comandante de Armas, Francisco José de Sousa Soares de Andréa, foi justamente porque este último pretendeu trazer para si o controle das funções de polícia. ${ }^{49}$

Além da pretensão de trazer o poder de polícia para o controle civil, no centro da justificativa dessa proposta de resolução estavam os tapuios. No corpo da proposta, Batista Campos dizia que os comandantes militares de distrito viviam "tomando os indígenas à condição de escravos e atropelando os habitantes menos civilizados do interior da província". Sendo a mão de obra dos tapuios um dos bens mais valiosos da província, não é estranho que oficiais militares estivessem envolvidos com o seu controle. Como bem salientou José Alves de Souza Jr., após a expulsão dos jesuítas, a maior porção da riqueza da província passou a ser controlada por funcionários públicos graduados, grande parte deles oficiais militares. ${ }^{50}$ Não é por acaso que, durante todo o tempo, a maioria dos principais opositores do partido de Batista Campos eram oficiais militares radicados no Pará que sempre deixaram claro sua resistência a grandes mudanças.

Reclamações sobre o arbítrio dos comandantes de distrito e do desvio da mão de obra tapuia das suas funções eram uma constante. Em 1825, o sacerdote de Óbidos relatava ao governo da província que o motivo por não terminar a construção da igreja dava-se por culpa dos comandantes dos índios em não os cederem, numa eterna contenda que fazia do "artigo índio" a "pedra de escândalo". ${ }^{11}$ Em 1830, na mesma região de Óbidos, era um comandante o denunciante, mas a reclamação era similar: o desvio de milicianos ligeiros que deveriam trabalhar no pesqueiro públi-

${ }^{47}$ IHGB - 105,6,23 - Coleção de proclamações, atas e outros impressos políticos relativos ao Pará entre 1827 e 1837 (doc. 3).

${ }^{48}$ MACHADO, André Roberto de A. A quebra da mola real das sociedades, op. cit., p. 146-147. Sobre o jornal $O$ Paranse, veja de COELHO, Geraldo Mártires. Anarquistas, demagogos e dissidentes: a imprensa liberal no Pará de 1822. Belém: Cejup, 1993.

${ }^{49}$ RAIOL, Domingos Antonio. Motins politicos, op. cit., p. 142-145. Anos mais tarde, Andréa voltará à província e será a principal figura vinculada à repressão aos cabanos.

${ }^{50}$ SOUZA JR., José Alves de. Constituição ou revolução: os projetos políticos para a emancipação do Grão-Pará e a atuação política de Filipe Patroni (1820-23). Dissertação de mestrado. Campinas: Unicamp, 1997, p. 13-85. Vicente Salles também salienta que, no período, fazia-se uma associação entre a condição de proprietário e a posse de uma patente de oficial militar. SALLES, Vicente. Memorial da Cabanagem, op. cit., cap. 4.

${ }^{51}$ APEP, Códice 713, doc. 109, de 6 de outubro de 1825. 
co e estavam sendo cedidos pelo administrador para serviços de particulares. ${ }^{52}$ Já em dezembro de 1831, portanto após a Agostada, o Conselho Geral da Província registrava em sua ata a leitura de uma representação vinda de Santarém em que se dizia que os comandantes militares de distrito não permitiam que os habitantes da vila gozassem plenamente os direitos da Constituição. ${ }^{53}$ Apesar de existirem várias queixas contra esta instituição, a resolução que pretendia extinguir os comandantes de distrito não foi aprovada pelo Conselho, como consta no resumo dos trabalhos deste órgão enviado para deputados e senadores. ${ }^{54}$ Isso dá a medida de como vários interesses tinham representação no Conselho Geral da Província.

Talvez por conta desta experiência, Batista Campos usou outra estratégia dois meses depois. Em fevereiro de 1830, Campos apresentou não uma proposta de resolução, mas de representação também sobre a questão da mão de obra indígena, o que acabou sendo aprovado pelo Conselho Geral. Quando vistas em conjunto as propostas de resolução e de representação, compreende-se melhor as ideias de Batista Campos sobre o tema. No resumo enviado ao Parlamento, consta apenas que se representava que fosse respeitado o espírito da lei que criou o já citado corpo de milicianos ligeiros e que, portanto, estes deviam ser considerados como "verdadeiras ordenanças". 55

Dessa forma tão resumida, é difícil compreender o sentido geral da proposta. No entanto, ela fica clara na exposição que a Comissão da Guerra da Câmara dos Deputados fez da representação, em 8 de julho de 1830. A comissão, que não tinha nenhum paraense como membro, dizia que havia um conflito entre autoridades civis e militares pelo controle da Milícia de Ligeiros, mas estes não faziam serviços armados e, sim, outros tipos de trabalhos. Por conta disso, a partir da representação, a comissão elaborou um projeto de lei que visava deixar esta questão clara e tirar definitivamente o controle desse corpo do comandante de Armas. ${ }^{56}$ Fica evidente, portanto, que a intenção de Batista Campos não era extinguir o corpo de milicianos

\footnotetext{
${ }^{52}$ APEP, Códice 888, doc. 48, de 21 de agosto de 1830. Documento cedido por Leandro Mahalem de Lima.

${ }^{53}$ Centro de Documentação e Informação - Arquivo Histórico da Câmara dos deputados - DF [CEDI] - Lata 68, maço 37, pasta 4 - Atas das sessões do Conselho Geral do Pará (1831-32), em 22 de dezembro de 1831. O Conselho Geral, que nesta data já não contava com os conselheiros que foram deportados na Agostada, tomou uma posição pouco firme sobre a questão, limitandose a enviar a representação à comissão responsável.

${ }^{54}$ CEDI - Lata 49, maço 21, pasta 1 - Lista dos trabalhos do Conselho Geral do Pará (1829-30). Há uma cópia em microfilme deste documento na Biblioteca Nacional - RJ [BN] - I,31,27,014 Conselho Geral da Província do Pará. Relação dos trabalhos pertencentes aos anos de 1829 e 1830.

${ }^{55} \mathrm{BN}$ - I,31,27,014 - Conselho Geral da Província do Pará. Relação dos trabalhos pertencentes aos anos de 1829 e 1830

${ }^{56}$ Anais do Parlamento Brasileiro. Câmara dos senhores deputados. Sessão de 1830. Rio de Janeiro: Tipografia de H. J. Pinto, 1878. [APB (1830)], em 8 de julho.
} 
ligeiros, nem a sua prestação de serviço. A intenção, novamente, era tirar esta instituição do comando militar e passá-la para o civil. ${ }^{57}$ Anos mais tarde, a edição de 8 de dezembro de 1832 do Publicador Amazoniense confirmava esta percepção do cônego Campos: então juiz de paz da Campina, expunha seu desejo de que os antigos membros da extinta Milícia de Ligeiro formassem uma companhia subordinada às ordens dos juízes de paz com o objetivo de procurar escravos fugidos. ${ }^{58}$

Apesar das intenções originais da proposta de representação feita por Batista Campos, o destino da Milícia de Ligeiros teria outro desfecho no Parlamento. Em 27 de novembro de 1830, houve uma intervenção nessa matéria do deputado eleito pelo Maranhão, Odorico Mendes, tido como um liberal por Batista Campos. ${ }^{59}$ Odorico Mendes propôs, nesta data, uma emenda que acabou substituindo o projeto de lei e que, em resumo, determinava a extinção completa das Milícias de Ligeiros do Pará. ${ }^{60}$ Partindo essa versão para o Senado, a recepção da proposta foi boa e a tramitação rápida. Na primeira discussão, em 18 de maio de 1831, o senador Saturnino se pronunciou pela extinção das Milícias de Ligeiros, dizendo que elas se prestavam apenas a explorar a mão de obra indígena. Essa percepção recebeu o apoio de outros senadores nesse dia e em 26 de maio, data da segunda discussão. Em todas essas ocasiões, a matéria teve o completo silêncio do representante do Pará no Senado, assim como fora na Câmara. Em 11 de junho de 1831, a extinção do corpo de Milicianos Ligeiros do Pará foi aprovada e seguiu para sanção. ${ }^{61}$ Apenas em 22 de agosto de 1831 torna-se lei, portanto após a Agostada. ${ }^{62}$

Por conta disso, como adiantado acima, não procedia a afirmação de Batista Campos, nas páginas de $O$ Publicador Amazoniense, de que uma das razões da deposição de Goiana seria o fim da Milícia de Ligeiros. Outra coisa a se salientar é que apesar da legislação sobre os Ligeiros não ter sido aprovada como original-

${ }^{57}$ Também interpretou dessa forma João Nei Eduardo da Silva, que pesquisou as atas do Conselho Geral do Pará entre 1829 e 1830. Aliás, pelo resumo não é possível identificar a autoria de Batista Campos para essa representação, mas Silva o identifica como o autor. Veja de SILVA, João Nei Eduardo da. Batista Campos: uma discussão biográfica na historiografia paraense, op. cit. Além disso, como se verá adiante, Lavor Papagaio reivindicou para Batista Campos a autoria dessa representação no número 60 da famosa Sentinela Maranhense na Guarita do Pará.

${ }^{58}$ IHGB - PER 32.14 - O Publicador Amazoniense. Edição de 8 de dezembro de 1832.

${ }^{59}$ BN - I-1,16,84 - Campos, João Batista Gonçalves. Carta ao senador José Martiniano de Alencar. Pará, 19 de novembro de 1833. Nessa carta, Batista Campos se diz surpreso pelo fato de Bráulio e Odorico, dois representantes do Maranhão que julgava liberais e com os quais tinha relações, não terem se posicionado contra a Agostada no Parlamento.

${ }^{60}$ APB (1830), em 27 de novembro.

${ }^{61}$ Anais do Senado do Império do Brasil. Sessão de 1831. Rio de Janeiro: s. i., 1914. [ASIB (1831)], em 18 e 26 de maio, 11 de junho.

${ }^{62}$ Coleção das leis do Império de 1831. Primeira parte. Rio de Janeiro: Tipografia Nacional, 1875, p. 76. 
mente pretendia Campos, o cônego utilizou a mudança a seu favor, compreendendo que ela era, de toda forma, um duro golpe contra os seus inimigos. Ainda durante a sua deportação para o interior da província por conta da Agostada, as atas da Câmara da vila de Alenquer registram, em 26 de março de 1832, a orientação de Batista Campos para que se publicasse um edital em que se divulgasse a extinção da Milícia de Ligeiros. ${ }^{63}$ Outro exemplo de uso político dessa lei a favor do cônego está no número 60 do periódico A Sentinella Maranhense na Guarita do Pará, de outubro de 1834, exemplar quase todo dedicado a uma longa defesa de Batista Campos contra as acusações do ex-presidente Machado de Oliveira, já em um momento em que Campos sofria uma pesada repressão do presidente Bernardo Lobo de Souza. ${ }^{64}$ Logo abaixo desta defesa, Lavor Papagaio, o editor da Sentinella, enumerava os serviços prestados pelo cônego, destacando que ele teria sido o autor das propostas para a extinção dos comandantes militares de distrito e dos Corpos de Ligeiros, o que, como visto acima, não era de todo verdade, já que Batista Campos não desejava o fim dessas milícias. ${ }^{65}$

Contudo, este esforço por se retratar como o idealizador do fim dos Ligeiros reforça a ideia, recorrentemente usada por seus adversários, de que o cônego gozava de prestígio entre os tapuios, muitos deles soldados, valendo-se do combate às formas de exploração compulsória da mão de obra como um instrumento de cooptação. Em um livro de 1843, Machado de Oliveira, por exemplo, chegou a afirmar que Batista Campos só foi reconhecido como presidente legal da província em partes do Baixo Amazonas, logo após a Agostada, porque disseminou a ideia de que todos seriam escravizados pelos portugueses se não o seguissem. ${ }^{66}$ Anos antes, o próprio cônego deixava mais claro qual era a ameaça que divulgava: em 1833, nas páginas de O Publicador Amazoniense, em mais de uma ocasião, Batista Campos afirmou que um dos planos dos executores do golpe de 1831 era reduzir à escravidão todos aqueles que, na suas palavras, eram "homens de cor" livres. ${ }^{67}$ Apesar de parecer absurda numa primeira leitura, de certa forma esta ameaça não era de todo descabida: afinal, em 1838, durante a presidência do já citado Soares de

${ }^{63}$ CEDI - Lata 115, maço 16, pasta 4 - Província (acontecimentos de agosto de 1831 no Pará). Ata da Câmara de Alenquer em 26 de março de 1832.

${ }^{64}$ Poucos meses depois, em janeiro de 1835, o presidente Bernardo Lobo de Souza será morto em um dos primeiros lances da Cabanagem. Batista Campos morre algumas semanas antes.

${ }^{65}$ BN-PR SOR 4750 - A Sentinella Maranhense na Guarita do Pará. Edição de 4 de outubro de 1834.

${ }^{66}$ OLIVEIRA, José Joaquim Machado de Oliveira. Juizo sobre as obras intituladas - Corographia paraense ou descrição physica, histórica e política da província do Grão-Pará, por Ignácio Accioli de Cerqueira e Silva e Ensaio corographico sobre a província do Pará, por Antonio Ladislau Monteiro Baena. Rio de Janeiro: Tipografia Imparcial de F. de P. Brito, 1843, p. 37.

${ }^{67}$ IHGB - PER 32.14 - O Publicador Amazoniense. Edições de 12 e 25 de janeiro de 1833. 
Andréa e da repressão aos cabanos, a Assembleia Provincial do Pará criou o Corpo de Trabalhadores que nada mais era que uma lei que permitiu obrigar ao trabalho compulsório todos os índios, mestiços e negros livres que não tivessem ocupação fixa. Um detalhe importante: para comandar esta fonte de mão de obra, a nova lei provincial recrutava justamente os oficiais das extintas Milícias de Ligeiros. ${ }^{68}$

Se não foi durante a administração do visconde de Goiana que as Milícias de Ligeiros tiveram seu fim, também é difícil mensurar qual foi a extensão das suas medidas para a extinção do pesqueiro, fábricas nacionais e roças comuns, todas instituições tocadas pelo trabalho compulsório de tapuios e apontadas por Goiana como uma das causas da sua deposição no já citado manifesto do Farol Maranhense. Chama-se atenção para isso pelo fato de que, ao acompanhar as discussões no Parlamento, surgem dúvidas se o visconde de Goiana tinha instrumentos legais para determinar o fim destes estabelecimentos. ${ }^{69}$ Afinal, em 1830, Manuel José de Araújo Franco, deputado eleito pelo Pará, apresentou um projeto justamente para extinguir os pesqueiros e as fábricas nacionais do Pará, mas sua proposta não teve seu mérito votado até onde esta pesquisa alcançou. ${ }^{70}$ Tanto era assim que, no ano seguinte, outro deputado eleito pelo Pará sugeriu um projeto na mesma linha que também não foi apreciado: João Fernandes de Vasconcelos propôs que fosse extinto o Arsenal da Marinha, outra instituição dependente do trabalho compulsório dos tapuios, e as fábricas nacionais que lhe forneciam material. ${ }^{71}$ Ainda em 1833 , o Parlamento discutia a venda das fábricas nacionais e do pesqueiro do Pará. ${ }^{22}$

${ }^{68}$ IHGB - Lata 415, pasta 8 - Collecção das leis provinciaes do Pará promulgadas na primeira secção que teve principio no dia 2 de março e findou no dia 15 de maio de 1838 e vão numeradas de 1 a 13. Pará: Tipografia Restaurada, 1838. Lei n. 02, de 25 de abril de 1838.

${ }^{69}$ Paralelamente aos debates no Parlamento, nas sessões de 1829-30 e 1830-31 do Conselho Geral da Província, as fábricas nacionais e projetos para civilização dos índios foram temas de debate e de organização de comissões. Contudo, não foi identificado nenhuma resolução sobre esses assuntos que tenha sido aprovada no Conselho e encaminhada ao parlamento. BN I-31,27,014 - Conselho Geral da Província do Pará. Relação dos trabalhos pertencentes a sessão dos anos de 1829 a 1830; BN - MS-602 (1) D. 17- Ata das sessões do Conselho Geral do Pará de 15 de dezembro de 1830 a 28 de fevereiro de 1831 .

${ }^{70}$ APB (1830), em 17 de julho.

${ }^{71}$ CEDI - Lata 56, maço 3, pasta 5. Ficam extintos o Arsenal da Marinha e os armazéns nacionais. Autoria de Fernandes Vasconcelos. Nos anais da câmara, o projeto é apenas citado, sem a sua transcrição integral. Anais do Parlamento Brasileiro. Câmara dos senhores deputados. Sessão de 1831. Rio de Janeiro: Tipografia de H. J. Pinto, 1878 [APB (1831)], em 20 de agosto.

${ }^{72}$ Anais do Parlamento Brasileiro. Câmara dos senhores deputados. Sessão de 1833. Rio de Janeiro: Tipografia da Viúva Pinto e Filho, 1887. [APB (1833], em 17 de junho. 
Se é difícil mensurar a extensão exata das ações do visconde de Goiana neste campo, há indícios de que, verdade ou boato, a notícia da extinção das roças comuns e fábricas nacionais correu a província e causou transtornos para a ordem estabelecida. Em 6 de dezembro de 1831, lia-se, no Conselho Geral, um requerimento que pedia o esclarecimento se de fato o visconde de Goiana havia acabado com as roças comuns como afirmava um "papel corrente" ${ }^{73}$ Em 1832 e 1833, ouvidores e juízes do interior da província enviavam correspondências para o presidente, reclamando que não conseguiam realizar os trabalhos públicos porque os tapuios se recusavam a prestar os serviços sob a alegação de que as fábricas nacionais tinham sido extintas, notícia que os correspondentes deixavam evidente que não sabiam se era verdadeira ou falsa. ${ }^{74}$

Se há controvérsias sobre as questões anteriores, não há dúvida de que uma atitude do visconde de Goiana, que atingia diretamente o uso da mão de obra dos tapuios, decidiu favoravelmente ao grupo de Batista Campos uma disputa que se arrastava há anos: coube a Goiana dar execução à perda de atribuições dos comandantes militares de distrito. A diferença em relação às questões anteriores era que Goiana contava com um amparo legal para isso. Isso porque, se no final de $1829 \mathrm{o}$ Conselho Geral do Pará barrou a proposta de resolução feita por Batista Campos para extinguir os comandantes militares de distrito, o Parlamento já estava apreciando uma resolução enviada pelo Conselho de São Pedro do Rio Grande do Sul que tratava desta matéria. O texto enxuto e bastante vago da lei de 28 de junho de $1830,{ }^{75}$ esconde o debate feito no Parlamento que revela uma enorme proximidade com a discussão realizada no Pará: mesmo sem extinguir o cargo, decidia-se retirar desses comandantes militares toda e qualquer atribuição que não fosse meramente militar, preocupando-se especialmente em negar a eles o poder de polícia, pois era necessário garantir ao juiz de paz, um poder civil, o comando da força policial. ${ }^{76}$ Transplantada a execução dessa lei para a realidade paraense, isso representava um golpe na estrutura de recrutamento de tapuios para o serviço compulsório.

Esta última medida, somada à posterior extinção das Milícias de Ligeiros, parece ter realmente causado preocupações ao grupo que se opunha ao partido de Batista Campos no tocante ao controle da mão de obra indígena. Tanto era

${ }^{73}$ CEDI - Lata 68, maço 37, pasta 4. Atas das sessões do Conselho Geral do Pará (1831-32). Em 6 de dezembro de 1831.

${ }^{74}$ APEP-Caixa 39-Série 13, doc. 28 e 54, respectivamente em 15 de junho de 1832 e 2 de maio de 1833.

${ }^{75}$ Collecção das leis do Império do Brazil de 1830. Parte primeira. Rio de Janeiro: Tipografia Nacional, 1876, p. 06.

${ }^{76}$ Anais do Parlamento Brasileiro. Câmara dos senhores deputados. Sessão de 1829. Rio de Janeiro: Tipografia de H. J. Pinto, 1877. [APB (1829)]. Em 23, 26, 27 e 30 de maio. 
assim que, na sessão do Conselho Geral da Província que se seguiu a Agostada, já sem a presença dos conselheiros deportados, foi colocado em análise um projeto de civilização dos índios oferecido por Antonio Ladislau Monteiro Baena, um militar português historicamente alinhado a várias figuras que executaram a deposição de Goiana. No dia 7 de dezembro de 1831, foi criada uma comissão para analisar o projeto, orientando-se para que esta buscasse aproveitar ao máximo a proposta inicial. ${ }^{77}$ Sob a justificativa de que o fim do tráfico negreiro era inevitável e que se fazia necessário garantir o suprimento da mão de obra, Baena sugeriu um projeto que tinha como premissa central a necessidade de criar mecanismos para obrigar os indígenas a trabalharem, já que para ele a ociosidade nestes indivíduos era inata. ${ }^{78}$ A proposta apresentada não só mantinha, em linhas gerais, uma pesada imposição de prestação de trabalho compulsório para os tapuios, chamados aqui de "índios cristãos", como pretendia modificar dois pontos da lei de 1798 continuamente criticados por aqueles que desejavam ter menores restrições para usar a mão de obra dos indígenas: em primeiro lugar, pela proposta, os paraenses poderiam voltar a fazer descimentos de nativos que estavam na selva. $\mathrm{O}$ segundo ponto de mudança proposto seria o controle dos movimentos dos tapuios, estabelecendo que estes não poderiam circular pelas vilas e povoados sem autorização. ${ }^{79}$ Como se vê, grupos do Pará pretendiam driblar o aumento de proteções legais para os tapuios que eram determinadas no Parlamento, com a proposição de leis locais. Contudo, até onde esta pesquisa alcançou, este projeto não conseguiu ser aprovado no Conselho Geral e seguir como proposta de resolução para o Parlamento, muito provavelmente por causa da reversão política no Pará após 1832, como se verá adiante. De toda maneira, a criação, em 1838, do já citado Corpo de Trabalhadores, através de uma lei provincial, demonstra que este projeto não foi abandonado.

Outra pretensão do visconde de Goiana que decidiria uma disputa relevante na província favoravelmente ao grupo de Batista Campos era a sua intenção de dissolver o corpo de voluntários armados sob o comando de Marco Antonio

77 CEDI - Lata 68, maço 37, pasta 4 - Atas das sessões do Conselho Geral do Pará (1831-32). Em 7 de dezembro de 1831.

${ }^{78}$ BAENA, Antonio L. M. Representação ao Conselho Geral da Província do Pará sobre a especial necessidade de um novo regulamento promotor da civilização dos índios da mesma província. $A n-$ naes da Biblioteca e Arquivo Público do Pará. Tomo II. Belém: Imprensa Oficial, 1902, p. 252-253.

${ }^{79}$ BAENA, Antonio L. M. Representação ao Conselho Geral da Província do Pará sobre a especial necessidade de um novo regulamento promotor da civilização dos índios da mesma província, op. cit., p. 252-53 e 269. A liberdade de trânsito destes indivíduos, garantida pela legislação de 1798, era frequentemente apontada como um dos grandes problemas da província, uma vez que possibilitava que grandes contingentes de tapuios abandonassem as vilas e povoados e voltassem para a selva. 
Rodrigues Martins. Essa força armada tinha se formado há poucos meses, no contexto do acirramento da disputa política impulsionada pela abdicação de d. Pedro I. Em 25 de maio de 1831, apenas dois dias depois da chegada da notícia da abdicação, Batista Campos, José Batista Camecran e Antonio Manuel de Souza Trovão, como membros do Conselho Presidencial, alegando que outras províncias também tinham tomado providências semelhantes, pediram o afastamento de Soares de Andréa do cargo de comandante de Armas, acusando-o de ser "absolutista teórico e prático". ${ }^{80}$ Os argumentos usados para firmar esta ideia estão diretamente relacionados às disputas citadas acima: acusava-se Andréa de querer subordinar o poder policial aos militares e de tratar os membros dos corpos de milícias com extrema crueldade, impondo castigos severos. Após um debate ríspido, a votação no Conselho ficou empatada, cabendo a José Felix Pereira de Burgos, então presidente da província, dar o desempate em favor da permanência de Andréa. Paralelamente a todos estes acontecimentos, chegou ao Conselho da Presidência um abaixo-assinado pedindo a conservação de Andréa no cargo, encabeçado por Marcos Antonio Rodrigues Martins. ${ }^{81}$

Para aqueles que acompanham os personagens políticos do Pará desde a década de 1820, em um primeiro momento causa estranheza que Marcos Martins aparecesse defendendo uma posição que se alinhava a grupos mais conservadores da província e oposta a Batista Campos. Afinal, Raiol o apontava como um dos que tiveram que fugir para os Estados Unidos em 1823 por seu envolvimento em um levante armado que pretendia romper os laços com Lisboa e, no ano seguinte, identifica-o como um dos supostos enviados por Pais de Andrade para fazer o Pará aderir à Confederação do Equador. Seu radicalismo era tanto, que chegou a trocar seu nome por Mundurucu Paiquicé entre 1823 e $1824 .{ }^{82}$ De fato, era o mesmo homem e muitos o acusavam de ter mudado de posição. Em seu já citado relato, Bittencourt dizia que Marcos Martins tinha sido partidário de Batista Campos, mas, em 1831, os dois já se odiavam. ${ }^{83}$ Em O Publicador Amazoniense, o próprio Batista Campos acusava Martins de traidor, de lhe dever "imensas

${ }^{80}$ RAIOL, Domingos Antonio. Motins politicos, op. cit., p. 152.

${ }^{81}$ O protagonismo de Marcos Martins para levantar esse abaixo-assinado não é mencionado por Raiol, mas estava registrado na Ata do Conselho Presidencial transcrito em jornais do período. IHGB - PER 27.11 - Correio do Amazonas. Edição de 4 de junho de 1831; IHGB - PER 32.13 - A Opinião. Edição de 1 de junho de 1831.

${ }^{82}$ RAIOL, Domingos Antonio. Motins políticos, op. cit., p. 79-80. Para uma crítica sobre a versão consagrada por Raiol de que o golpe de abril de 1824 teria como objetivo alinhar a província a Pernambuco, veja de MACHADO, André Roberto de A. A quebra da mola real das sociedades, op. cit., cap. 4.

${ }^{83}$ IHGB - 1,3,12 - BITTENCOURT, José Maria da Silva. Apontamentos relativos aos acontecimentos do Pará, de 1831 a 1836. 
obrigações" e de ter estado a serviço dos restauradores em $1831 .{ }^{84}$ Além de não existir nenhuma prova que ligue a futura Agostada a uma tentativa de restauração na Amazônia, apesar das inúmeras acusações nesse sentido, também não foi este o lugar reivindicado por Marcos Martins.

Na edição de $1^{\circ}$ de junho de 1831 do seu jornal A Opinião, Martins dava publicidade à Ata do Conselho Presidencial em que se votou a permanência de Andréa no Comando das Armas da província. Ao comentar esse acontecimento, fazia duras críticas aos que propuseram a deposição, dizendo que estavam sugerindo uma medida "desorganizadora e anticonstitucional", indo no sentido contrário de uma mensagem anterior feita pelo Conselho aos paraenses, em que se pedia "moderação" ${ }^{85}$ Esta seria a primeira de muitas vezes que Martins usaria a "moderação" como ideia força, fazendo uma associação cada vez mais evidente com o grupo de parlamentares liderados por Evaristo da Veiga que serão identificados nos jornais paraenses como "moderados".

Poucos dias após o embate no Conselho Presidencial, Marcos Martins voltou a ser protagonista. No dia 2 de junho, correu a notícia de um levante militar em Belém em que os soldados exigiam o pagamento dos soldos atrasados, a reunião da Câmara Municipal e a demissão de autoridades. Quando a força do governo já estava reprimindo os rebeldes, Marcos Martins chegou comandando uma força de voluntários armados que, segundo jornais da época, somavam 500 homens. ${ }^{86}$ Dissolvido o levante, o Conselho Presidencial, sem a presença de Batista Campos e com a oposição de José Batista Camecran, decidiu oficializar o corpo de voluntários armados sob o comando de Marcos Martins. ${ }^{87}$ Coube a Marcelino Cardoso, conselheiro que posteriormente assumirá a presidência com a Agostada, chamar esta força de "Guarda Nacional" o que, apesar da impropriedade, acabou sendo a forma pela qual este corpo armado ficou conhecido.

Pois será justamente este um dos pontos de atrito com o visconde de Goiana a partir da sua posse, em meados de julho de 1831. Sabendo que a lei de criação da Guarda Nacional estava sendo votada no Rio de Janeiro, o nome parecia lhe conferir alguma legalidade e novidade, mas este corpo armado nada mais era que a repetição das milícias voluntárias que surgiram no Pará durante a independência para reprimir grupos que desejavam mudanças mais radicais e as tropas de

\footnotetext{
${ }^{84}$ IHGB - PER 32.14 - O Publicador Amazoniense. Edição de 12 de janeiro de 1833.

${ }^{85}$ IHGB - PER 32.13 - A Opinião. Edição de 1 de junho de 1831.

${ }^{86}$ IHGB - PER 27.11 - Correio do Amazonas. Edição de 11 de junho de 1831.

${ }^{87} \mathrm{Na}$ ata do Conselho Presidencial fez-se um adendo, dizendo que Batista Campos posteriormente concordara com a criação deste corpo armado. IHGB - PER 27.11 - Correio do Amazonas. Edição de 18 de junho de 1831 .
} 
$1^{\circ}$ e $2^{\circ}$ linhas. ${ }^{88}$ Demonstra bem isso o fato de que, nesse corpo armado, não se elegiam os oficiais, traço marcante da primeira fase da Guarda Nacional. ${ }^{89}$ Ao contrário disso, primeiro surgiu um líder, no caso Marcos Martins, e esse passou a convocar voluntários na imprensa para se subordinarem a ele. ${ }^{90}$ Contudo, em uma questão essa milícia conseguiu estar mais perto dos objetivos dos criadores da Guarda Nacional do que a própria: afinal, quando esta organização foi, tempos depois, legalmente constituída no Pará passou a ser protagonista de sublevações, chegando a ser desativada em 1836 pelo então presidente Soares de Andréa que a considerava uma força cabana. ${ }^{91}$ Enquanto isso, a tropa comandada por Marcos Martins foi realmente um freio a pretensões de mudanças radicais, um instrumento de defesa da propriedade e do Estado, tal como tinha sido idealizada a Guarda Nacional pelos grupos que estavam alinhados no Rio de Janeiro ao pensamento de Evaristo da Veiga expresso nas páginas do Aurora Fluminense. ${ }^{92}$

Se no ano seguinte Evaristo da Veiga fez no Parlamento a defesa das mudanças sem revolução, ${ }^{93}$ Marcos Martins fez disso uma bandeira logo após o levante militar que ajudou a sufocar e sua "Guarda Nacional" foi apresentada como um instrumento para este projeto que tinha a "moderação" como palavra-chave repetida à exaustão. Apesar de Batista Campos, através de impressos, ter negado qualquer participação no levante militar, ${ }^{94} \operatorname{logo}$ Marcos Martins insinuou seu envolvimento dizendo que "a opinião pública pronuncia-se mui claramente contra um homem que é sempre a mola secreta dos alarmes e tumultos do Pará". ${ }^{95}$ Como se vê, a imagem que se construía do cônego era a antítese da "moderação".

${ }^{88}$ A lei para criação da Guarda Nacional foi apresentada em maio de 1831, mas só foi aprovada em agosto. Veja de HOLANDA, Sérgio Buarque. In; CASTRO, Jeanne Berrance. A milícia cidadã: a guarda nacional de 1831 a 1850. $2^{\mathrm{a}}$ edição. São Paulo: Ed. Nacional, 1979. Sobre as milícias voluntárias no Pará no período da independência, veja de MACHADO, André Roberto de A. $A$ quebra da mola real das sociedades, op. cit., cap. 4.

${ }^{89}$ CASTRO, Jeanne Berrance. A milícia cidadã, op. cit., p. 135-145.

${ }^{90}$ IHGB - PER 32.13 - A Opinião. Edição de 8 de junho de 1831.

${ }^{91}$ HURLEY, Jorge. Traços cabanos: 13 de maio (1836-1936). Belém: Instituto Lauro Sodré, 1936, p. 10; CASTRO, Jeanne Berrance. A milícia cidadã, op. cit., p. 03-16.

${ }^{92}$ CASTRO, Jeanne Berrance. A milícia cidadã, op. cit., p. 13-14. SOUZA, Otávio Tarquínio de. Evaristo da Veiga. São Paulo: Cia Editora Nacional, 1939, cap. 5.

${ }^{93}$ Anais do Parlamento Brasileiro. Câmara dos senhores deputados. Sessão de 1832. Rio de Janeiro: Tipografia de H. J. Pinto, 1879. [APB (1832)], em 12 de maio.

${ }^{94}$ IHGB - 115,6,17 - Carta aos cidadãos paraenses, verdadeiros independentes, amigos da liberdade, residentes nesta cidade e no interior da província. Carta n. 02.

${ }^{95} \mathrm{Um}$ dos argumentos para o envolvimento de Batista Campos era o fato dos soldados terem pedido a reunião da Câmara, quando, para Marcos Martins, aqueles soldados nem sabiam o que era Câmara. IHGB - PER 32.13 - A Opinião. Edição de 1 de junho de 1831. 
Na edição de 15 de junho de 1831 do A Opinião, Marcos Martins deixava de apenas insinuar: Batista Campos era expressamente acusado de ser o mentor do levante militar de 2 de junho com base em uma denúncia feita pelo comandante de Armas, Soares de Andréa. Depois de alarmar os paraenses, o jornal abria espaço para um longo comentário com o significativo título: "A união sustenta a liberdade; a moderação acredita-a". Nesse texto dizia que a França sofreu por conta dos princípios revolucionários de pessoas como Robespierre e Danton, mas que agora se erguia seguindo "um rei cidadão" e "dignos representantes", dando exemplo de "ordem e moderação". Buscando associar-se a este último modelo político, Marcos Martins já tentava vincular suas iniciativas como correspondente à de grupos de expressão nacional, especialmente de destacados parlamentares que serão identificados no Pará como membros do "partido moderado":

É preciso pois que os Brasileiros nesta crise tão arriscada, unânimes e resignados ouçam e sigam a vontade da nação, que lhes for manifestada por seus dignos Representantes: que as vozes dos Vergueiros, dos Linos, dos Bernardos de Vasconcellos, dos Odoricos, e de outros, que fizeram tão forte e resistente oposição às tentativas do despotismo, atendam agora para que haja união e ordem para que a divisão dos ânimos e anarquia não nos conduzam ao futuro desastroso que fomos ameaçados. (...) Atentem os Brasileiros o que lhes dissemos do coração e pelo que lhes disserem os escritores liberais que tanto têm trabalhado em todas as províncias para a salvação da Pátria e que agora lhes mostram quanto convém estar unidos e ser moderados. ${ }^{96}$

Apoiados nessas ideias é que os partidários de Marcos Martins acusaram visconde de Goiana de, ao pretender extinguir a dita "Guarda Nacional", estar prejudicando a defesa da moderação e abrindo caminho para a subversão social, para eles representada no partido liderado por Batista Campos. Ao observar esses discursos, não é estranho que os argumentos de que a Agostada foi uma ação para salvar a província tenha sido acolhido por parte significativa do Parlamento. ${ }^{97} \mathrm{De}$ toda forma, a ruptura institucional sempre será lembrada por Batista Campos e seus aliados como argumento para cobrar dos deputados e senadores uma punição severa para os que depuseram o visconde de Goiana. Como se verá a partir

${ }^{96}$ IHGB - PER 32.13 - A Opinião. Edição de 15 de junho de 1831.

${ }^{97}$ De forma semelhante, os ditos moderados usavam a imprensa no Rio de Janeiro para rejeitar o Jacobinismo e buscavam manter o processo de mudanças nas mãos da elite política. Veja de GUIMARÃES, Lucia M. P. Liberalismo moderado: postulados ideológicos e práticas políticas no período regencial. In: GUIMARÃES, L. M. P; PRADO, Maria E. (org.). O liberalismo no Brasil imperial: origens, conceitos e práticas. Rio de Janeiro: Renavam / Uerj, 2001, p. 103-126. 
de agora, o Parlamento foi decisivo nos desdobramentos da disputa política no Grão-Pará após o golpe de 7 de agosto de 1831.

\section{0 fiel da balança}

Como citado no começo do artigo, os paraenses substituíram dois dos seus três representantes na Câmara dos Deputados entre a primeira e a segunda legislatura. Mais significativo que a troca de nomes foi a mudança do perfil político dos escolhidos entre as duas votações.

A eleição para a primeira legislatura aconteceu no contexto de uma pesada repressão à guerra civil que cobriu a província até 1825 . Além disso, o então presidente do Grão-Pará, José de Araújo Rozo, prendera ou deportara homens ligados a Batista Campos, além do próprio, sob a acusação de estarem promovendo a união da província com a Confederação do Equador. Em meio a esse ambiente político, os homens escolhidos para representarem o Pará na primeira legislatura tinham um perfil bastante conservador, excetuando-se João Candido Deus e Silva, não por acaso eleito apenas como segundo suplente e o único dos deputados a conseguir uma nova vaga para a segunda legislatura. ${ }^{98}$ Por gozar de um cargo vitalício, o senador José Joaquim Nabuco de Araújo foi o único remanescente deste núcleo mais conservador que, durante a primeira legislatura, manteve-se estritamente fiel não só aos ministérios, mas especialmente ao imperador. O futuro barão de Itapoã, nascido na Bahia em 1764, além de formado em Coimbra tinha exercido vários cargos na alta burocracia do Império português e do Império do Brasil, estando ligado aos grupos conservadores do Pará através do seu irmão José Thomaz Nabuco de Araújo, um dos deputados eleitos para a primeira legislatura, que trabalhou para a sua eleição ao Senado. ${ }^{99}$ Apesar da ampla visão do Império, o barão de Itapoã teve uma apagada atuação no Senado, chegando, nessa segunda legislatura, quase à nulidade. Nesse sentido, não foram encontradas ações públicas do senador Nabuco de Araújo em relação à Agostada, mesmo que entre os principais executores desse golpe estivessem homens como José de Araújo Rozo que,

${ }^{98}$ Sobre a eleição dos paraenses para a primeira legislatura e o perfil desses representantes, veja de MACHADO, André Roberto de A. Redesenhando caminhos, op. cit.

${ }^{99}$ NABUCO, Joaquim Nabuco. Um estadista do Império. São Paulo: Instituto Progresso Editorial, s. d., p. 3-16; BARATA, Carlos Eduardo de A.; BUENO, Antonio Henrique da C. Dicionário das famílias brasileiras. Volume 2. São Paulo: Ibero América, s.d., p. 1.595-96; LYRA, A. Tavares de. O Senado do Império. Revista do IHGB. Rio de Janeiro, vol. 153, 1928, p. 234-235. Biblioteca Nacional. Catálogo da Exposição de História do Brasil. Brasília: Editora da UNB, 1981, p. 535. MELLO, Teixeira de. Ephemerides Nacionaes. Rio de Janeiro: Tipografia da Gazeta de Notícias, 1881, vol. I, p. 242. 
estando na presidência no Pará entre 1824 e 1825, foi fundamental para a eleição do seu irmão, José Thomaz, ao cargo de deputado na primeira legislatura. ${ }^{100}$ Como já mencionado, o outro representante do Pará que já exercera o cargo durante a primeira legislatura era o deputado, reeleito, João Candido de Deus e Silva. Tal como o senador Nabuco de Araújo, Deus e Silva também tinha se formado em Coimbra e exercera cargos públicos de relevo, ainda que de menor expressão, em várias partes do antigo Império português antes de chegar ao Parlamento do Império do Brasil. ${ }^{101}$ Vicente Salles classificou esse deputado como um "liberal exaltado" e chegou a especular se não teria sido um contato entre os liberais paraenses e os que estavam na Corte. ${ }^{102}$ Contudo, é difícil, à luz da sua atuação na Câmara, sustentar tanto o radicalismo desse parlamentar quanto o seu alinhamento ao grupo de Batista Campos, certamente o que estava na cabeça de Vicente Salles ao pensar em "exaltados" no Pará. Afinal, durante a segunda legislatura, Deus e Silva esteve alinhado ao grupo de Evaristo da Veiga nas principais votações, ainda que os ditos "moderados" fossem acusados, no Pará, de acobertar os executores da Agostada. Além disso, como se verá, Deus e Silva não denunciou na Câmara a deposição do visconde de Goiana e aprovou, como membro da Comissão de Constituição e Justiça, um projeto de anistia para os golpistas a pedido Marcos Martins, deixando claro que não tinha compromissos com o partido de Batista Campos.

Os dois novos deputados do Pará na segunda legislatura também eram bacharéis em Direito. Apesar da intensa procura, não foi possível encontrar referências sobre eles na bibliografia, apenas pequenas citações em documentos. ${ }^{103}$ Isso, somado a outros indícios, indica que se tratavam de figuras apenas de expressão

${ }^{100}$ SEIXAS, Romualdo Antonio. Memórias do marquês de Santa Cruz, arcebispo da Bahia. Rio de Janeiro: Tipografia Nacional, 1861, p. 33-41. Sendo Rozo uma peça chave das articulações políticas de José Thomaz, pode-se supor que o ex-presidente também tinha sido importante para a eleição do futuro barão de Itapoã ao cargo de senador.

${ }^{101}$ BAENA, Antonio L. M. Compêndio das eras da Província do Pará. Belém: UFPA, 1969, p. 300 e 329; BLAKE, A.V.A. Sacramento. Diccionário bibliographico brasileiro. Rio de Janeiro: Imprensa Nacional, 1937, tomo 3; MELLO, Teixeira de. Ephemerides nacionaes, op. cit., vol. II, p. 70; SALLES, Vicente. Memorial da Cabanagem, op. cit., p. 103-104. Dicionário bibliográfico português. Estudos de Innocêncio F. da Silva aplicáveis a Portugal e Brasil. Continuados e ampliados por P. V. Brito Aranha. Revisto por Gomes de Brito e Álvaro Neves. Lisboa: Imprensa Nacional, 1858-1923. 23 volumes (versão eletrônica). Agradeço a Tâmis Parron pela indicação do Dicionário bibliográfico português. Um perfil mais elaborado deste deputado e sua atuação na primeira legislatura estão em MACHADO, André Roberto de A. Redesenhando caminhos, op. cit.

${ }^{102}$ SALLES, Vicente. Memorial da Cabanagem, op. cit., p. 75 e 103-104.

${ }^{103}$ Para se ter uma ideia da escassez de informações sobre esses personagens, esses são os únicos representantes do Pará, entre 1826 a 1840, que não possuem nenhum tipo de dado no livro de Nogueira e Firmo, famoso por fornecer indicações bibliográficas sobre parlamentares no Império. Veja de NOGUEIRA, Otaciano; FIRMO, João Sereno. Parlamentares do Império. Brasília: Senado Federal, 1973. 
local. O primeiro deles era Manuel José de Araújo Franco, identificado em uma das sessões da Câmara como o titular do cargo de ouvidor no Pará. ${ }^{104}$ Tendo ficado adoentado durante boa parte dessa legislatura, Araújo Franco cumpriu um mandato pouco expressivo, não ficando totalmente claro seu posicionamento a favor dos ministérios ou da oposição. Suas proposições ficaram concentradas em pedidos de benefícios pontuais para o Pará, como criação de escolas e a extinção do açougue nacional, postura que tinha sido a tônica dos representantes paraenses na primeira legislatura, mas que só ele manterá nesse quadriênio. ${ }^{105}$ Durante o auge das discussões sobre a Agostada no Pará, não há registro de atuação parlamentar de Araújo Franco na Câmara, mesmo em outros assuntos, o que faz supor que estivesse ausente por doença, como já havia acontecido em outros meses. Alguns documentos, no entanto, indicam que este deputado estava alinhado ao partido de Batista Campos no Pará. Em O Publicador Amazoniense, por exemplo, Campos indicava Araújo Franco como um dos homens que haviam sido traídos por Marcos Martins. ${ }^{106}$ Outro indício pode ser encontrado nas páginas de $O$ Sagitário, periódico redigido por Luiz José Lazier e combatido pela facção de Batista Campos. ${ }^{107}$ A edição de 25 de fevereiro de 1830 de $O$ Sagitário foi utilizada quase que totalmente por Lazier para combater a campanha contra o comandante das Armas que era promovida nas páginas de $O$ Telegrafo Paraense e $A$ voz das Amazonas pelo cônego Silvestre Antunes Pereira da Serra, então um dos maiores aliados de Batista Campos. A certa altura, Lazier diz que iria retomar seu ataque contra o cônego Serra do ponto em que estava até ser preso, de acordo com as conveniências de seus inimigos, por Araújo Franco e pelo "sr. Vasconcellos", possivelmente referindo-se ao terceiro deputado eleito pelos paraenses. ${ }^{108}$

João Fernandes de Vasconcelos foi, sem dúvida, o representante do Pará mais alinhado aos ditos "exaltados" nessa legislatura. Provavelmente ele era um dos três irmãos Vasconcelos processados no final de 1821 sob a acusação de terem se associado a Filipe Patroni para divulgar ideias de ruptura com Lisboa e o fim da escravidão, episódio ainda hoje com muitos pontos a esclarecer e comprovar. ${ }^{109}$

\footnotetext{
${ }^{104}$ Nessa sessão, pede-se a redução do salário de ouvidor de Araújo Franco por ele estar recebendo vencimentos como deputado pelo Pará. APB (1830), em 28 de junho.

${ }^{105}$ APB (1830), em 17 de julho e 21 de agosto. Sobre essa tendência dos representantes do Pará na primeira legislatura, veja de MACHADO, André Roberto de A. Redesenhando caminhos, op. cit.

${ }^{106}$ IHGB - PER 32.14 - O Publicador Amazoniense. Edição de 12 de janeiro de 1833.

${ }^{107}$ Batista Campos chega a a acusar Lazier de usar O Sargitário para a causa restauradora. IHGB - 115,6,17 - Carta aos cidadãos paraenses, verdadeiros independentes, residentes nesta cidade e no interior da província. Carta n. 02.

${ }^{108} \mathrm{BN}$ - PR SOR 4751 - O Sagitário. Edição de 25 de fevereiro de 1830.

${ }^{109}$ Os irmãos Vasconcelos processados eram João Fernandes de Vasconcelos, Julião Fernandes de
} 
Apesar do seu alinhamento explícito, em alguns momentos, a atuação de Fernandes de Vasconcelos frustrou a expectativa dos partidários de Batista Campos. Exemplo disso foi o fato de Fernandes de Vasconcelos não ter se empenhado nos debates sobre as "reformas no sentido federal", ${ }^{110}$ principal bandeira dos jornais controlados pelos aliados do cônego Campos após a Agostada. Provavelmente, isso se deu pela sistemática oposição que Fernandes de Vasconcelos fez aos ditos "moderados". ${ }^{111} \mathrm{Na}$ mesma lógica, também deve ter sido esta a razão pela qual Fernandes de Vasconcelos votou contra o fim da vitaliciedade dos senadores, ação que provavelmente decretou seu abandono político pelos ditos "exaltados" do Pará, já que em várias ocasiões O Publicador Amazoniense apontou a manutenção da vitaliciedade dos senadores, chamada pejorativamente de "Câmara dos Aristocratas", como o maior absurdo da segunda legislatura. ${ }^{112}$ Apesar desses "tropeços", Fernandes de Vasconcelos foi na Câmara, de fato, a voz do grupo político atingido pela deposição do visconde de Goiana da presidência do Pará.

Logo ao chegar na Câmara dos Deputados, Fernandes de Vasconcelos apoiou firmemente uma representação de um particular do Pará, Joaquim Antonio de Macedo Tupinambá, que pedia a punição do antigo e do atual ministro do Império, respectivamente José Clemente Pereira e o marquês de Caravelas, por terem mandado José Felix Pereira de Burgos como presidente da província. ${ }^{113}$ Esta ati-

Vasconcelos e Manuel Fernandes de Vasconcelos. Esse é um episódio sempre relembrado pelos historiadores que tentam provar o progressivo interesse dos paraenses em romper com Lisboa. No entanto, há uma série de interrogações quanto a veracidade das acusações contra os irmãos Vasconcelos. Aparentemente, esta foi, sobretudo, uma tentativa da Junta Provisória de atingir a credibilidade de Patroni em Lisboa, já que este fazia pesadas críticas ao governo paraense. Sobre isso, veja de MACHADO, André Roberto de A. A quebra da mola real das socidades, op. cit., p. 139-140. Sobre o episódio dos irmãos Vasconcelos, veja de BAENA, Antonio L. M. Compêndio das eras da província do Pará. Belém: UFPA, 1969, p. 328; MUNIZ, Palma. Adesão do GrãoPará à independência e outros ensaios. Belém: Conselho Estadual de Cultura, 1973, p. 129-144.

${ }^{110}$ Os jornais dos partidários do cônego Batista Campos defendiam que o Ato Adicional promovesse uma reforma constitucional que representasse grande autonomia para administração das províncias. Sintomaticamente, chamavam essa pretensão de "reformas em sentido federal".

${ }^{111}$ Tudo indica que esta não era uma ação isolada. Marcello Basile aponta que alguns dos parlamentares considerados como "exaltados" uniram-se em alguns momentos aos restauradores para impor derrotas aos moderados. Veja de BASILE, Marcello O. N. de C. O Império em construção: projetos de Brasil e ação política na Corte regencial. Tese de doutorado. Rio de Janeiro: UFRJ, 2004, p. 142.

${ }^{112}$ APB(1832),p.283. IHGB-PER32.14-OPublicador Amazoniense. Edição de22 de dezembrode 1832 e 4 de fevereiro de 1833. Na ocasião, o redator de O Publicador Amazoniense considerava que apenas os senadores Vergueiro, Borges e Alencar podiam não ser considerados "criaturas do ex-imperador".

${ }^{113}$ APB (1830), em 8 de junho, 21 de julho, 20 de setembro e 4 de novembro. Joaquim Antonio Tupinambá era um dos personagens apontados por Raiol como supostamente enviados por Pais de Andrade para tentar promover a Confederação do Equador no Pará, tal como já citado. RAIOL, Domingos Antonio. Motins políticos, op. cit., p. 79. 
tude provava seu alinhamento político com o grupo de Batista Campos por dois motivos: em primeiro lugar, causava embaraços a Burgos, um presidente odiado por essa facção, especialmente por ter evitado a deposição de Soares de Andréa do cargo de comandante de Armas, em 1831, como já citado. ${ }^{114}$ Em segundo lugar, compartilhava a crença desse partido de que o Parlamento era uma espécie de guardião das leis e o último recurso contra o despotismo. Ao acompanhar os trabalhos do Conselho Geral da Província, percebe-se que este partido utilizava esta instituição para enviar várias representações ao Parlamento nessa direção. Para frustração desse grupo, no entanto, o destino de quase todos esses papéis foi morrer nas gavetas das comissões ou ser encaminhado para outros poderes. ${ }^{115}$

Possivelmente, foi por perceber o pouco resultado prático conseguido pelas denúncias encaminhadas ao Parlamento contra o desrespeito às leis que Fernandes de Vasconcelos resolveu enviar ao jovem imperador seus protestos contra a deposição do visconde de Goiana, exigindo providências. Datado de 12 de novembro de 1831, o protesto de Fernandes de Vasconcelos identificava José de Araújo Roso, Marcos Martins e Bittencourt como os líderes da Agostada, acusada por ele de ser um movimento a favor da submissão da província ao governo de d. Miguel. Dizia que os golpistas queriam dar um "garrote em todos os beneméritos e verdadeiros paraenses”, entre os quais ele incluía Batista Campos, descrito por ele como um homem "que tem sido sempre no Pará o sustentáculo da Constituição e da liberdade". 116

Os desdobramentos da Agostada paraense motivaram debates acalorados no Parlamento nos anos seguintes, especialmente em 1833. Contudo, o protesto de Fernandes de Vasconcelos foi a única denúncia do golpe em seu momento inicial feita por membros da Câmara ou do Senado. Trinta anos depois, Bittencourt comemorava o isolamento dessa denúncia, dizendo que a Regência não tomou nenhuma providência pelo fato de Fernandes de Vasconcelos não ter nenhum prestígio e ser conhecido, segundo ele, pela fama de ladrão de cavalos. ${ }^{117}$ Apesar do protesto de Fernandes Vasconcelos não ter sido capaz de deter os golpistas, não é verdade que

\footnotetext{
${ }^{114}$ No ano seguinte, o próprio Fernandes de Vasconcelos terá a iniciativa de pedir a punição de João Paulo dos Santos Barreto por queixas que se faziam dele em relação ao período em que esteve no comando das armas do Pará. Deve-se lembrar que Barreto travou uma intensa disputa com o cônego Silvestre Antunes Pereira da Serra, um dos partidários de Batista Campos, que o criticava através da imprensa. APB (1831), em 23 de julho. IHGB - 115,6,35-36 - Telegrafo Paraense. Edição de 28 de março de 1829.

${ }^{115}$ APB (1830), em 25 de setembro.

${ }^{116}$ BN 102,5,289 - VASCONCELOS, João Fernandes de. Requerimento a d. Pedro I (sic). Rio de Janeiro: Tipografia de Gueffier e C, 1831.

${ }^{117}$ IHGB - 1,3,12 - Apontamentos relativos aos acontecimentos do Pará, de 1831 a 1836 que lhe oferece o seu amigo, o general José Maria da Silva Bittencourt (1864).
} 
a Regência não tenha tomado atitudes depois dessa denúncia, como afirmou Bittencourt. Afinal, quatorze dias depois, em 26 de novembro, Feijó, como ministro da Justiça, enviou uma carta ao presidente do Pará mandando reverter o golpe e trazer os deportados de volta aos seus cargos. Contudo, isto não teve um resultado prático porque o Conselho da Presidência recusou-se a cumprir esta ordem, uma vez que ela significaria dar posse a Batista Campos como presidente. ${ }^{118}$ Além disso, ainda que não tenha sido por outros parlamentares, neste intervalo o Parlamento continuou recebendo denúncias da Agostada e cartas exigindo uma tomada de posição. Esses protestos vieram, e em grande quantidade, justamente em função de um acontecimento já antecipado por Fernandes de Vasconcelos: algumas vilas se recusaram a reconhecer o governo de Belém após a deposição de Goiana.

No Arquivo Histórico da Câmara dos Deputados é possível contar mais de vinte cartas e atas enviadas no primeiro semestre de 1832 aos "representantes da nação" e recebidas ainda nesse mesmo ano. Todas essas correspondências eram enviadas pelas câmaras municipais de vila próximas a Santarém: Faro, Franca, Alter do Chão, Boim, Alenquer, Óbidos, Vila de Moz, Gurupá, além da própria Santarém. Todas elas também tinham um discurso comum e tratavam de assuntos semelhantes. Em primeiro lugar, recusavam a autoridade do governo de Belém, pediam a punição dos golpistas e o retorno do visconde de Goiana ao posto de presidente. Enquanto isso, Batista Campos, na condição de vice, era reconhecido como a maior autoridade da província. ${ }^{119}$

Isso, obviamente, não se dava por acaso. Após o golpe de 7 de agosto de 1831, o cônego Campos foi colocado em uma embarcação em que seria levado ao presídio da distante São João do Crato. Contudo, ele conseguiu fugir na região de Óbidos, nas proximidades de Santarém, e passou a ganhar adesões das vilas citadas. Nas atas das câmaras municipais são citados, inclusive, eventos de que Batista Campos participou na condição de presidente da província. Possivelmente o mais impressionante deles foi a cerimônia de reconhecimento de d. Pedro II na Vila de Óbidos, em 2 de fevereiro de 1832. Em outras vilas da região também se procedeu ao juramento de obediência a d. Pedro II, sempre reclamando que

${ }^{118}$ APEP, Códice 901, doc. 29, em 27 de janeiro de 1832. Sobre esse episódio, veja de RAIOL, Domingos A. Motins políticos, op. cit., p. 236-240.

${ }^{119}$ CEDI - Lata 115, maço 16, pasta 4 - Província (acontecimentos de agosto de 1831 no Pará). Em oito de agosto de 1832, na Câmara dos Deputados é mencionado o recebimento de parte dessas correspondências, classificadas como representações, sem entrar no mérito do seu conteúdo, encaminhando-as para a Comissão de Constituição. APB (1832), em 08 de agosto. Além das questões citadas, nessas cartas reclamava-se do não cumprimento da já citada ordem da regência, de novembro de 1831, que mandava reverter o golpe. 
as câmaras municipais tomavam essa iniciativa sem qualquer orientação do governo de Belém, insinuando assim que o comando da província estava nas mãos de restauradores. Contudo, apesar de não ser a única, a cerimônia de Óbidos foi especial. Além de Batista Campos ocupar o papel de presidente, autoridades de outras vilas foram assistir ao evento e puderam presenciar a cena de ramos de café sendo empunhados como símbolo dos "patriotas liberais". ${ }^{120}$

As correspondências acima, oriundas do Baixo Amazonas, deixavam clara a expectativa dos seus remetentes de que o Parlamento atuasse como árbitro nos conflitos do Pará e que exercesse o seu papel de guardião das leis ao punir os golpistas.

Não bastasse isso, ainda em 1832, deputados e senadores também passaram a receber correspondências da região do Alto Amazonas que relacionavam a Agostada a uma nova reivindicação local: a transformação da Comarca do Rio Negro em província independente. No dia 12 de abril de 1832, uma sublevação militar controlou a comarca e causou a morte da principal autoridade militar da região. Machado de Oliveira, o novo presidente do Pará enviado pela Corte e empossado no final de fevereiro de 1832, foi rápido ao tentar estabelecer uma motivação para esses conflitos: em carta ao ministro da Guerra, no mês seguinte, Machado de Oliveira dizia não ter dados suficientes sobre os acontecimentos, mas acreditava que a razão do levante era a agitação política causada por Batista Campos no interior da província. ${ }^{121}$ Dias antes, em 30 de abril, Machado de Oliveira já tinha escrito ao próprio Batista Campos, censurando-o por continuar tentando ser reconhecido como principal autoridade do Pará no interior da província, mesmo depois de ter recebido a notícia da chegada do novo presidente enviado pela Corte. Sem dizer a data precisa, Raiol afirmou que Batista Campos cumpriu rapidamente a ordem de Machado de Oliveira para retornar a Belém e não foi preso, o que foi encarado por seus adversários, ainda segundo este autor, como um ato de "proteção" do então presidente ao cônego. ${ }^{122}$

Sem a data precisa da chegada de Batista Campos a Belém, não é possível saber se ele já estava ou não na capital quando a rebelião no Alto Amazonas tornouse mais séria: em 22 de junho de 1832, um conselho reuniu-se na Comarca e fez uma série de exigências que submetia à aprovação da Assembleia e da Regência, estando entre elas a transformação do Rio Negro em província independente. ${ }^{123}$

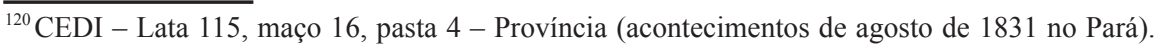
A ata da sessão de reconhecimento de d. Pedro II na vila de Óbidos também está transcrita em RAIOL, Domingos Antonio. Motins políticos, op. cit., p. 243-244.

${ }^{121}$ APEP, Códice 899, doc. 72, em 19 de maio de 1832.

${ }^{122}$ RAIOL, Domingos Antonio. Motins politicos, op. cit., p. 263-264.

${ }^{123}$ RAIOL, Domingos Antonio. Motins politicos, op. cit., p. 257-259.
} 
Como bem observado por Arthur Cezar Ferreira Reis, apesar de várias deduções nesse sentido, até hoje não foram apresentados documentos que comprovem a ligação entre Batista Campos e a rebeldia no Alto Amazonas. ${ }^{124}$ Ao contrário disso, em 1833, o cônego Silvestre Antunes Pereira da Serra, partidário de Campos, dizia no periódico A Luz da Verdade que os liberais não tinham apoiado motins de soldados e nem a tentativa de separação do Rio Negro, e que haviam deixado esta posição clara por diversas vezes em folhas públicas. ${ }^{125}$ Contudo, também é verdade que, no Conselho da Presidência, Batista Campos se opôs à repressão militar do movimento no Rio Negro, sugerindo que se deixasse o Parlamento decidir pela criação ou não da nova província. ${ }^{126}$ Além disso, sem um desfecho favorável para os autonomistas no Parlamento, o cônego defendeu, no ano seguinte, que o Conselho Geral da província propusesse uma resolução para a criação de um governo próprio no Rio Negro, ainda que subalterno a Belém. ${ }^{127}$

Independentemente da questão acima, o que mais interessa a este estudo é que, em 1832, começaram a ser enviadas correspondências do Alto Amazonas para o Parlamento em que se dava conta dos últimos acontecimentos, muitas vezes trazendo denúncias da Agostada para o centro do debate. Logo no início da sessão de 1833, foi lida, na Câmara dos Deputados, a primeira destas correspondências: uma ata do já citado conselho extraordinário que se reuniu no Lugar da Barra, então centro da Comarca do Rio Negro. ${ }^{128}$ Nos Anais do Parlamento brasileiro não é transcrito o teor da mensagem, mas é possível encontrá-la no Arquivo Histórico da Câmara dos Deputados: datada de 22 de junho de 1832, a ata pede a criação da província independente e menciona a tirania de Belém como o principal motivo desse pedido. Não é feita nenhuma menção direta ao golpe de 7 de agosto de $1831 .{ }^{129}$ Contudo, ao longo de 1833, na Câmara, são mencionadas várias outras correspondências de vilas do Rio Negro pedindo a

\footnotetext{
${ }^{124}$ REIS, Arthur Cezar Ferreira. A autonomia do Amazonas, op. cit., p. 39-70.

${ }^{125}$ IHGB - PER 32.12 - A Luz da Verdade. Edição de 30 de março de 1833.

${ }^{126}$ RAIOL, Domingos Antonio. Motins politicos, op. cit., p. 267-268.

${ }^{127}$ De fato, foi criada uma resolução nestes termos pelo Conselho Geral da Província um mês após a sugestão de Campos. Contudo, apesar de lida em 1834, o mérito da proposta não foi debatido no Parlamento sob a alegação de que já havia um projeto para a criação da província do Rio Negro e que esta medida deveria ter prioridade. De toda forma, a criação da província do Rio Negro, apesar das várias discussões nos anos seguintes, só foi efetivada em 1850. Veja de MACHADO, André Roberto de A. Redesenhando caminhos, op. cit.

${ }^{128}$ Anais do Parlamento brasileiro. Câmara dos senhores deputados. Sessão de 1833. Rio de Janeiro: Tipografia da Viúva Pinto e Filho, 1887. [APB (1833)], em 16 de abril. Apesar das correspondências serem encaminhadas, de modo geral, aos "representantes da nação", apenas na Câmara dos Deputados foram discutidas tanto a sublevação no Rio Negro quanto as cartas vindas de lá.

${ }^{129} \mathrm{CEDI}$ - Lata 98, maço 1, pasta 10 - Parecer sobre divisão territorial.
} 
criação da nova província, deixando o tema permanentemente na pauta. ${ }^{130}$ As duas únicas mensagens localizadas, vindas das vilas de Serpa e de Silves, relacionam diretamente a Agostada ao movimento no Rio Negro. Em linhas gerais, ambas dizem que o golpe de 7 de agosto em Belém trouxe indignação à região, tornando o desejo de separação inevitável. ${ }^{131}$

A partir daí, na Câmara, não havia mais como silenciar ou não ter uma posição em relação à Agostada. Apesar do levante no Rio Negro ter sido controlado por uma ação militar já em agosto de $1832,{ }^{132}$ a gravidade do fato acirrou os ânimos no Rio de Janeiro. Na condição de ministro, em maio de 1833, Vergueiro falava na Câmara sobre as dificuldades de controlar os ânimos no interior, citando o levante no Rio Negro como emblemático. ${ }^{133}$ Isso ganha importância porque Vergueiro tinha uma visão pública sobre esse acontecimento: afinal, a já citada afirmação do cônego Silvestre Antunes Pereira da Serra, nas folhas de A Luz da Verdade, de que os liberais paraenses não tinham apoiado a separação do Rio Negro fazia parte de uma resposta furiosa a uma carta do ministro Vergueiro que foi considerada favorável aos golpistas. ${ }^{134}$ Ainda no mesmo mês, outro ministro, Honório Carneiro Leão, também se pronunciava na Câmara sobre esse assunto fazendo fortes censuras. Para o então ministro da Justiça, os acontecimentos no Rio Negro eram o ponto mais grave de uma contenda entre duas facções que se alternavam no poder em Belém e perseguiam os que estavam temporariamente fora do governo. ${ }^{135}$

As declarações dos dois ministros eram motivadas pelos acontecimentos no Rio Negro, mas também já sinalizavam uma outra fase da disputa no Pará, justamente a que colocou o Parlamento numa posição de personagem ativo. Essa nova fase dos desdobramentos do golpe de 1831 já estava anunciada em uma carta do presidente Machado de Oliveira ao ministro da Justiça, em agosto de 1832. Na correspondência, o presidente dizia buscar um tom conciliatório entre o grupo que depôs Goiana e o que foi deportado. É preciso lembrar que logo que chegou a Belém, em fevereiro de 1832, Oliveira mandou soltar os presos vítimas da Agostada e os deportados tornarem às suas residências. A contrapartida

\footnotetext{
${ }^{130}$ APB (1830), em 11 $, 12,15$ e 20 de junho, 6 de julho. Nos Anais do Parlamento apenas é mencionado pedido de criação da nova província, sem transcrever o conteúdo integral das mensagens.

${ }^{131}$ CEDI - Lata 84, maço 7, pasta 1 - Petições sobre províncias (Pará - visconde de Goiana).

${ }^{132}$ A expedição militar tinha partido de Belém em maio como reação ao levante que tinha causado a morte da principal autoridade militar da Comarca. RAIOL, Domingos Antonio. Motins políticos, op. cit., p. 264-271.

${ }^{133}$ APB (1833), em 8 de maio.

${ }^{134}$ IHGB - PER 32.12 - A Luz da Verdade. Edição de 30 de março de 1833. A carta de Vergueiro será melhor explorada adiante.

${ }^{135}$ APB (1833), em 14 de maio.
} 
para o outro grupo está expressa nessa carta ao Ministério: o presidente dizia ter cumprido a orientação do governo de não tomar a iniciativa em processar os golpistas. Contudo, Machado de Oliveira dizia que este procedimento não foi seguido por aqueles que tinham sido prejudicados pela Agostada, já que agora faziam denúncias e abriam processos contra seus antigos algozes. ${ }^{136}$

A peça fundamental desse novo equilíbrio de forças no Pará foi o cargo de juiz de paz. Considerada a primeira grande conquista dos liberais no Império do Brasil, ${ }^{137}$ o juiz de paz era um leigo eleito localmente que, no princípio, tinha funções bem restritas, cuidando de reunir provas, interrogar suspeitos e, sobretudo, promover conciliações. Contudo, em 1832, o Código do Processo Penal ampliou muito o poder punitivo do juiz de paz que passou até a decidir penas de detenção por seis meses. ${ }^{138}$ Thomas Flory alertou que o princípio conciliador em que estava idealizada a criação do juiz de paz nunca pôde se efetivar, já que, por ser um cargo eletivo, os escolhidos tinham compromissos com facções da província. ${ }^{139}$ Como se verá, este foi um argumento utilizado na Câmara e no Senado para afirmar que havia perseguições contra os executores da deposição do visconde de Goiana e que os processos abertos não eram isentos.

O fato é que membros da facção diretamente atingida pela Agostada passaram a ocupar postos de juiz de paz depois da posse de Machado de Oliveira como presidente. Esse era um cargo bem ao gosto desse partido, uma vez que, eleito localmente, o poder central tinha pouca capacidade de intervenção sobre os titulares desses postos. ${ }^{140}$ Em dezembro de 1832, Batista Campos fazia uma prestação de contas do seu trabalho como juiz de paz da Campina nas folhas de O Publicador Amazoniense. Ao listar os presos, dizia que quase todos eram portugueses que estavam portando armas, tinham injuriado patrulhas ou particulares. Sua preocupação, dita expressamente, era desmentir que o cargo de juiz de paz estivesse sendo usado como vingança contra os executores da Agostada. ${ }^{141} \mathrm{Na}$

\footnotetext{
${ }^{136}$ APEP, Códice 901, doc. 48, em 25 de agosto de 1832.

${ }^{137}$ DOLHNIKOFF, Miriam. O pacto imperial: origens do federalismo no Brasil. São Paulo: Globo, 2005, p. 83-86.

${ }^{138}$ FLORY, Thomas. El juez de paz y el jurado en el Brasil imperial, op. cit., cap. 4. Leis de 1828 e 1831 também já tinham ampliado o poder dos juízes de paz.

${ }^{139}$ FLORY, Thomas. El juez de paz y el jurado en el Brasil imperial, op. cit., p. 100. A ideia de que o juiz de paz servia a facções foi utilizada pelos conservadores, posteriormente, para eliminar o seu caráter eletivo, substituindo-o por funcionários escolhidos pelo governo.

${ }^{140}$ DOLHNIKOFF, Miriam. O pacto imperial, op. cit., p. 84.

${ }^{141}$ IHGB - PER 32.14 - O Publicador Amazoniense. Edição de 8 de dezembro de 1832. Em carta de Machado de Oliveira, em meados de 1833, Batista Campos aparece como suplente do cargo de juiz de paz da freguesia de Santa Anna da Campina, pertencente a capital. Nessa correspondência, Machado de Oliveira diz ter advertido Campos por julgar que cometia excessos ao prender
} 
mesma edição de O Publicador Amazoniense, Campos dizia que também haveria prestação de contas do juiz de paz da Sé. Por documentos de 1833, tudo leva a crer que o titular desse cargo fosse o cônego Silvestre Antunes Pereira da Serra, já citado como partidário de Campos, o que significava que esta facção ocupava este posto nas duas freguesias de Belém. ${ }^{142}$ Vingança ou não, o fato é que o número de processos contra executores da deposição do visconde de Goiana crescia e isso era utilizado politicamente pelo grupo de Campos. Como dito antes, na eleição para deputados da terceira legislatura, O Publicador Amazoniense dizia que "agostenses" que estavam sendo processados não podiam receber votos. ${ }^{143}$ No começo de 1833, no mesmo jornal, Batista Campos dizia que os golpistas não perdiam por esperar e que brevemente se cumpririam várias ordens de prisão. ${ }^{144}$

Ao mesmo tempo em que isso acontecia, pela imprensa o grupo de Batista Campos buscava desfazer a suposta identificação entre os agostenses e os moderados, elogiando a atuação desse último grupo no Parlamento. A essa altura, O Publicador Amazoniense fazia uma forte campanha pelas ditas "reformas em sentido federal", defendendo que, na Corte, os moderados e os exaltados estavam unidos nesse objetivo. ${ }^{145}$ No começo de 1833 , o mesmo jornal buscou relacionar Marcos Martins com os restauradores e desacreditar qualquer vinculação entre os moderados e a deposição do visconde de Goiana: “Aqui, senhores, nunca houve, nem há, partido moderado, que é liberal, sim o de Marcos que esta encarregado pelo Ministério do ex-imperador para presidir com João Paulo dos Santos a sociedade da coluna criada por este nesta cidade (...)". ${ }^{146}$ Perceba-se que apesar de reivindicar para si a condição de liberal, Campos não se identificou como um moderado mesmo quando desejava uma aproximação. Como se verá, este grupo paraense já começava a aceitar a designação de exaltado, mesmo que isto representasse a associação à desordem.

pessoas apenas pela posse de armas. APEP, Códice 901, doc. 109, em 31 de julho de 1833.

${ }^{142}$ CEDI - Lata 89, maço 27, pasta 3 - Impressos sobre a mudança da presidência do Pará e outras.

${ }^{143}$ IHGB - PER 32.14 - O Publicador Amazoniense. Edição de 15 de dezembro de 1832.

${ }^{144}$ IHGB - PER 32.14 - O Publicador Amazoniense. Edição de 4 de janeiro de 1833.

${ }^{145}$ IHGB - PER 32.14 - O Publicador Amazoniense. Edição de 22 de dezembro de 1832.

${ }^{146}$ IHGB - PER 32.14 - O Publicador Amazoniense. Edição de 12 de janeiro de 1833. O termo "coluna”, utilizado diversas vezes por Batista Campos, referia-se aos restauradores. Como já dito, não há nenhuma evidência que relacione a Agostada aos restauradores. A acusação de restaurador foi uma arma utilizada indistintamente no Pará, mesmo em algumas ocasiões em que representavam um contrassenso. O próprio Batista Campos não só será acusado deste "crime" por Machado de Oliveira, quando os dois rompem politicamente, como morrerá com esta fama disseminada na imprensa oficial pelo presidente seguinte. 
A contrapartida prática foi a tentativa de tornar-se palatável ao governo central e ao Parlamento, fazendo vários elogios a este último na imprensa. A única exceção nesse movimento aconteceu em dezembro de 1832, quando $O$ Publicador Amazoniense publicou e censurou uma resposta do então ministro Lino Coutinho a uma felicitação enviada pelo Conselho Geral da Província à Assembleia na sessão que seguiu a Agostada. Em resumo, a ideia da felicitação foi de Marcos Martins que comparava como momentos de salvação da ordem pública o sete de abril, data de abdicação de d. Pedro I, com o 7 de agosto no Pará. ${ }^{147} \mathrm{O}$ problema é que Lino Coutinho não esboçou qualquer crítica e ainda louvou o interesse pelo "sossego da província", o que fazia os agostenses, segundo Batista Campos, usarem a resposta do ministro como um atestado de que nada lhes aconteceria. ${ }^{148}$ Quase dois meses depois, em 9 de fevereiro, a Câmara Municipal de Belém endereçou uma representação à Assembleia em que criticava a resposta de Lino Coutinho, dizendo que ela dava a entender que o governo central não queria punir os agostenses. Da mesma forma, pedia a deputados e senadores que fizessem o ex-ministro sofrer um processo de responsabilidade. ${ }^{149}$ Como se vê, mais uma vez o Parlamento era invocado como o último recurso, o guardião das leis a quem cabia punir quem desrespeitasse as "regras do jogo".

Deve-se ressaltar que isso não era um mero jogo de aparências. A denúncia contra Lino Coutinho causou furor na Câmara dos Deputados. Demonstra isso o fato de se ter criado uma comissão especialmente para analisar as acusações da Câmara de Belém. Em cinco ocasiões durante o mês de maio de 1833, o assunto entrou na pauta dos deputados, mostrando a sua importância. Contudo, a cópia da correspondência original de Lino Coutinho não foi encontrada na secretaria do governo, frustrando o pedido da comissão especial que acabou, por conta disso, fazendo um parecer inconcluso. ${ }^{150}$ Este foi um dos fatores que contribuíram para "esfriar" o assunto na Câmara. O outro, talvez mais importante, é que personagens ligados à deposição de Goiana agora estavam no Rio de Janeiro tentando influenciar o Parlamento e o Ministério ao seu favor.

Em agosto de 1832, Marcos Martins e dois de seus aliados na imprensa, José Soares de Azevedo e João Batista Tenreiro Aranha, fugiram às pressas de Belém

${ }^{147}$ CEDI - Lata 68, maço 37, pasta 4 - Atas das sessões do Conselho Geral (1831-32). Sessões de 5 e 9 de dezembro de 1831. A felicitação à Assembleia está transcrita em RAIOL, Domingos Antonio. Motins políticos, op. cit., p. 235.

${ }^{148}$ A carta de Lino Coutinho está transcrita em IHGB - PER 32.14 - O Publicador Amazoniense. Edição de 15 de dezembro de 1832 .

${ }^{149}$ CEDI - Lata 84, maço 7, pasta 1 - Petições sobre províncias (Pará - visconde de Goiana).

${ }^{150} \mathrm{APB}(1833)$, em 6, 7, 11,21 e30 de maio. Não foi eleito nenhum representante do Pará para esta comissão. 
em direção aos Estados Unidos para não serem presos pelas críticas que fizeram a Machado de Oliveira no jornal $O$ Despertador. Esses redatores, que já eram parceiros no periódico A Opinião, tinham feito uma severa censura ao presidente por ter dissolvido a milícia de voluntários liderada por Marcos Martins, a dita "Guarda Nacional", dizendo que o presidente estava tirando as armas das "classes industriais e produtoras" e permitindo que os juízes de paz armassem a "ralé esfarrapada". ${ }^{151}$ Em janeiro de 1833, provavelmente pela circulação de cartas, já se sabia que estes indivíduos tinham saído dos Estados Unidos e chegado ao Rio de Janeiro, pois O Publicador Amazoniense fazia esforços para desacreditar a possibilidade de Marcos Martins e seus aliados conseguirem influenciar a Corte, salvar os agostenses e trocar a presidência do Pará por alguém a seu gosto. ${ }^{152}$ De fato, Marcos Martins ressurge publicamente no local que tinha se tornado uma extensão do palco das disputas políticas do Pará: em 13 de maio de 1833, é apresentado na Câmara dos Deputados um pedido de anistia feito por Marcos Martins que se identificava como procurador dos pronunciados pela sedição de 7 de agosto no Pará. ${ }^{153}$

Os argumentos utilizados na Câmara e no Senado para discutir esse pedido de anistia demonstram que Marcos Martins tinha conseguido impor sua visão para parlamentares e ministros importantes. A já citada fala do ministro Honório à Câmara, pronunciada um dia depois do pedido de anistia, desenhava o atual estado do Pará como tenebroso: segundo ele, a facção prejudicada pela Agostada agora se vingava, utilizando os cargos de juiz de paz para prender cidadãos de "consideração social". ${ }^{154}$ O próprio parecer da Comissão de Constituição e Justiça endossa essa visão: recomenda a anistia porque havia muitos proprietários e negociantes entre os que estavam sendo presos por envolvimento na Agostada. Ressalte-se que a aprovação desse parecer na Comissão contou com o voto favorável de Deus e Silva, um dos deputados eleitos pelo Pará, o que põe por terra a ideia de que ele estivesse ligado a Batista Campos. O único voto contrário foi de Costa Ferreira, eleito pelo Maranhão, censurando que na petição de anistia tenha se comparado o 7 de abril ao 7 de agosto no Pará. ${ }^{155}$

\footnotetext{
${ }^{151}$ SALLES, Vicente. Memorial da Cabanagem, op. cit., p. 113-114. RAIOL, Domingos Antonio. Motins políticos, op. cit., p. 274. Os responsáveis pelo O Despertador tinham sido condenados a dois anos de prisão.

${ }^{152}$ IHGB - PER 32.14 - O Publicador Amazoniense. Edição de 18 de janeiro de 1833.

${ }^{153}$ APB (1833), em 13 de maio.

${ }^{154}$ APB (1833), em 14 de maio. Em 4 de setembro, já sem a condição de ministro, Honório segue a mesma linha para defender a anistia no Pará. APB (1833), em 04 de setembro.

${ }^{155}$ APB (1833), em 31 de maio.
} 
No Senado, o debate seguia a mesma linha do parecer da Comissão de Constituição e Justiça da Câmara. Durante a discussão de uma anistia para Minas Gerais, o marquês de Caravelas, eleito pela Bahia, pediu a extensão do benefício ao Pará. Sua narrativa dos acontecimentos demonstra como a versão dos agostenses tinha se proliferado na Assembleia: segundo o marquês, o golpe no Pará tinha ocorrido porque o presidente dava ouvidos ao "chefe dos anarquistas", numa clara referência a Batista Campos. Ainda segundo o marquês de Caravelas, a anistia era necessária porque o "chefe dos anarquistas" agora era juiz de paz e perseguia seus inimigos com a abertura de processos ${ }^{156} \mathrm{O}$ próprio senador Alencar, que Batista Campos considerava um liberal e de quem tentou se aproximar, ${ }^{157}$ defendeu a extensão da anistia ao Pará, dizendo que haviam mais de 200 pessoas sendo processadas, num terrível clima de perseguição. ${ }^{158}$

No ano anterior, um pedido de anistia que beneficiaria os agostenses já tinha dividido a representação do Pará. Cinco dias depois de serem anunciadas na Câmara as cartas do Baixo Amazonas que denunciavam a deposição de Goiana, propunha-se uma emenda para um projeto de anistia no Maranhão que, se aprovada, perdoaria todos os crimes políticos no Império desde 7 de abril de 1831. Tal como em 1833, Deus e Silva votou a favor. Araújo Franco e Fernandes Vasconcellos, ligados ao partido do cônego Campos, votaram contra. ${ }^{159}$ Em 1833, após o parecer favorável à anistia da Comissão de Constituição e Justiça e diante dos discursos na Câmara e no Senado simpáticos aos agostenses, Fernandes de Vasconcellos parece ter percebido que o perdão seria aprovado e, talvez por isso, propôs uma emenda para que o benefício alcançasse todos os crimes de opinião política no Pará até o final de $1832 .{ }^{160}$ Isso evitaria que fossem abertos novos processos por conta dos acontecimentos no Rio Negro, o que representava uma salvaguarda para os seus aliados na província. Contudo, isso já não bastaria. Novos acontecimentos tinham precipitado o rompimento do grupo de Batista Campos com a facção dominante no Parlamento e no Ministério, levando a uma nova quebra da ordem institucional.

\footnotetext{
${ }^{156}$ Anais do Senado do Império do Brasil. Sessão de 1833. Rio de Janeiro: s. i., 1916. [ASIB (1833)], em 30 de maio.

${ }^{157} \mathrm{BN}$ - I-1, 16,84 - Campos, João Batista Gonçalves. Carta ao senador José Maritiniano de Alencar, enviando-lhe notícias políticas do Pará, onde um movimento absolutista e restaurador tem atacado os políticos liberais através da imprensa. Pará, 19 de novembro de 1833.

${ }^{158}$ ASIB (1833), em 31 de maio.

${ }^{159}$ APB (1832), em 13 de agosto.

${ }^{160}$ APB (1833), em 8 de junho. Araújo Franco não se manifestou em 1833 sobre o tema, provavelmente por estar afastado em razão de doença.
} 
Em março de 1833, foi amplamente reproduzida na imprensa paraense a carta de Vergueiro, então ministro do Império, que trazia muitos argumentos que, posteriormente, circularam no Parlamento nos debates sobre o Pará. Nela, o ministro fazia uma severa crítica ao que ele chamava de "sistemática perseguição" a pessoas da "mais elevada representação" da província que estavam sendo processadas por sedição. Em seguida, mandava Machado de Oliveira repreender os juízes e o informava que seria substituído, em breve, no posto de presidente. ${ }^{161}$ Batista Campos publicou integralmente a carta de Vergueiro em O Publicador Amazoniense, comentando, abaixo, ser absurda a benevolência que se pretendia ter com homens que tinham cometido crimes políticos. ${ }^{162}$ Àquela altura, temia-se, sobretudo, que a saída de Machado de Oliveira representasse uma reversão do quadro político no Pará.

Contudo, seria em outro jornal, escrito por Campos e pelo cônego Serra que se faria a crítica mais contundente à carta de Vergueiro, representando a reversão das tentativas de aproximação deste grupo com o partido que naquele momento controlava o Parlamento e o Ministério. Na já citada edição de 30 de março de 1833, os redatores do A Luz da Verdade desfaziam o esforço de O Publicador Amazoniense nos meses anteriores e, agora, negavam que os moderados fossem liberais. Ao contrário, diziam que o Ministério queria arrasar os verdadeiros liberais, aos quais chamava de "exaltados", "anarquistas" e "demagogos". Dizia também que houve, em relação à Agostada, "uma espécie de liga entre o Evaristo, o Januário, o Feijó e todos os seus para meter aquele negócio no esquecimento" o que, segundo os redatores, por pouco não teve êxito. Na tentativa de mostrar a articulação dos agostenses com membros da Corte, $A$ Luz da Verdade afirmava que Marcos Martins tinha procurado tanto moderados como caramurus no Rio de Janeiro e a cada grupo tinha tentado convencer que a deposição de Goiana obedecia aos seus anseios. Em relação a esta aparente contradição, os redatores ironizavam: "Mas ah! Que agora nos lembra que já lá (no Rio) se fez o casamento de caramurus e moderados e dizem que foi canônico!".

No entanto, a grande marca dessa edição foi a afirmação reiterada de que a não punição dos agostenses representava transformar a Constituição em letra morta: "Agora vemos que essa igualdade da Lei, de que trata a Constituição é ilusória porquanto a moderação não quer que se pratique essa sorte (...) se liberal é réu, se é amigo dos moderados ou da facção lusa é perseguido". Ainda sobre a suposta perseguição de que falava Vergueiro, os redatores afirmavam que não

\footnotetext{
${ }^{161}$ A carta de Vergueiro está transcrita em RAIOL, Domingos Antonio. Motins políticos, op. cit., p. 275.

${ }^{162}$ IHGB - PER 32.14 - O Publicador Amazoniense. Edição de 25 de março de 1833.
} 
eram centenas, mas apenas 60 os pronunciados no Pará e que todos respondiam em liberdade, ao contrário dos exaltados que estavam presos no Rio de Janeiro. Sobre o fato de serem pessoas de "elevada representação", Campos e Serra ironizavam, perguntando se o ministro estava se referindo a taverneiros e lojistas, pois eles eram a maioria dos envolvidos. No fim, criticam a orientação de Vergueiro para que os juízes executassem as leis em harmonia com a política:

Executar a lei à risca não é hoje bom, pois ela deve executar-se conforme a política. Ora se isto é como entendemos, adeus leis que todas elas vão com a política. Por exemplo, gente grande, de representação, comete um delito, a política pede que se não faça caso disso e mesmo se embarace a quem quiser proceder contra eles \& c. ${ }^{163}$

Quando Feijó, como ministro da Justiça, censurou os agostenses e mandou reverter o golpe, em novembro de 1831, disse que a província corria um sério risco: a de que seus habitantes perdessem a crença de que a lei precisava ser fielmente observada. ${ }^{164}$ A edição de $A$ Luz da Verdade mostra que este acabou sendo o resultado desse processo iniciado em 7 de agosto de 1831. Para o partido liderado por Batista Campos, o Parlamento tinha falhado na sua função de "fiel da balança", de guardião das leis, que poderia impor o cumprimento das "regras do jogo" pelas facções na província e até mesmo no Ministério. O resultado prático disso foi mais uma ruptura no quadro institucional: apesar de chegarem na província em abril de 1833, os novos presidente e comandante de Armas enviados pela Corte não conseguiram tomar posse. Uma série de abaixo-assinados e impressos circularam em Belém, escritos por Batista Campos ou seus aliados, pedindo que Machado de Oliveira ficasse, pois consideravam que os novos mandatários vinham a pedido dos agostenses. ${ }^{165}$ Como um grupo, liderado pelo português Jales, prometeu garantir a posse do novo presidente pela força, houve um amplo conflito armado pelas ruas de Belém, resultando em 95 mortes e a vitória da facção que estava resolvida a não dar posse aos novos enviados pela

\footnotetext{
${ }^{163}$ IHGB - PER 32.12 - A Luz da Verdade. Edição de 30 de março de 1833. Além do comentário final dos redatores, a transcrição da carta de Vergueiro é pontuada por notas de rodapé em que são rebatidas as afirmações do ministro. Serra e Campos também criticaram a decisão de retirar Machado de Oliveira da presidência por outro periódico, O Paraguassu. IHGB - PER 33.20 - O Paraguaçu. Edição de 1 de março de 1833.

${ }^{164}$ Como já mencionado, esta ordem de Feijó não foi cumprida e os agostenses só saíram da presidência com a chegada de Machado de Oliveira. RAIOL, Domingos Antonio. Motins políticos, op. cit., p. 236.

${ }^{165}$ Parte desses documentos foi enviado depois para o Parlamento, como forma de justificar o fato de não ter sido dada posse ao novo presidente. CEDI - Lata 89, maço 27, pasta 3 - Impressos sobre a mudança da presidência do Pará e outras.
} 
Corte. ${ }^{166}$ Essas notícias chegaram ainda neste ano ao Parlamento e os projetos de anistia que vinham sendo discutidos foram substituídos por uma permissão de dois meses para o governo anistiar qualquer crime político, o que acabou cobrindo tanto os agostenses como também os envolvidos neste novo episódio no Pará. ${ }^{167}$

Apesar de receberem este benefício, o perdão aos envolvidos na deposição do visconde de Goiana trouxe um profundo descrédito do Parlamento para o grupo liderado por Batista Campos. A partir de então, as intervenções das instituições do poder central na vida da província, entre as quais estavam o perdão aos agostenses pelo Parlamento, foram vistas como insuportáveis, podendo levar à guerra civil. Consequentemente, o Ato Adicional passou a ser defendido por este partido como a última esperança: "as reformas em sentido liberal serão a nossa salvação, elas serão o Anjo da Paz que nos arrancará das bordas do precipício". ${ }^{168}$ De toda forma, a descrença na capacidade das instituições do Império em arbitrar os conflitos passava a ficar registrada no cabeçalho que acompanhou, desde o final de 1833, O Publicador Amazoniense, pouco mais de um ano antes da Cabanagem: "Todos os brasileiros são obrigados a pegar em armas para sustentar a Independência e a Integridade do Império, defendê-la dos seus inimigos externos ou internos". ${ }^{169}$

\section{Referências bibliográficas}

BAENA, Antonio L. M. Compêndio das eras da província do Pará. Belém: UFPA, 1969.

BAENA, Antonio L. M. Ensaio corographico sobre a província do Pará, por Antonio Ladislau Monteiro Baena. Rio de Janeiro: Tipografia Imparcial de F. de P. Brito, 1843.

BARATA, Carlos Eduardo de A.; BUENO, Antonio Henrique da C. Dicionário das famílias brasileiras. Volume 2. São Paulo: Ibero América, s.d.

BARATA, Manuel. Formação histórica do Pará. Belém: UFPA, 1973.

BASILE, Marcello Otávio Néri de Campos. OImpério em construção: projetos de Brasil e ação política na Corte regencial. Tese de doutorado. Rio de Janeiro: UFRJ, 2004.

BEZERRA NETO, José Maia. Escravidão negra no Grão-Pará (séculos XVIII-XIX). Belém: Paka-tatu, s.d.

CASTRO, Jeanne Berrance. A milícia cidadã: a guarda nacional de 1831 a 1850. $2^{a}$ edição. São Paulo: Ed. Nacional, 1979.

\footnotetext{
${ }^{166}$ RAIOL, Domingos Antonio. Motins politicos, op. cit., p. 337-343.

${ }^{167}$ APB (1833), em 5 e 17 de julho, 4 e 24 de setembro. ASIB (1833), em 22 de agosto.

${ }^{168}$ IHGB - PER 32.12 - A Luz da Verdade. Edição de 30 de março de 1833.

${ }^{169}$ IHGB-PER 32.14-OPublicador Amazoniense. Edição de 2 de dezembro de 1833. Esse cabeçalho era uma citação da Constituição do Império. A mesma frase servia de cabeçalho para o jornal "Exaltado", publicado na Corte. Sobre isso, veja de BASILE, Marcello. O Império em construção, op. cit., p. 136.
} 
CHIAVENATO, Julio José. Cabanagem, o povo no poder. São Paulo: Brasiliense, 1984.

CLEARY, David. Lost altogether to the civilised world: race and Cabanagem in Northern Brazil, 1750 to 1850. Comparative studies in society and history, 1998.

COELHO, Geraldo Mártires. Anarquistas, demagogos e dissidentes: a imprensa liberal no Pará de 1822. Belém: Cejup, 1993.

COELHO, Geraldo Mártires. Onde fica a Corte do senhor imperador? In: JANCSÓ, István (org.). Brasil: formação do Estado e da nação. São Paulo - Ijuí: Hucitec / Fapesp / Unijui, 2003.

COSTA, Emília Viotti da. Liberalismo: teoria e prática. In: Idem. Da monarquia à república: momentos decisivos. $7^{\mathrm{a}}$ edição. São Paulo: Unesp, 1999.

CUNHA, Manuela Carneiro da (org.). Legislação indigenista no século XIX: uma compilação (1808-1889). São Paulo: Edusp / Comissão Pró-Índio de São Paulo, 1992.

DOLHNIKOFF, Miriam. O pacto imperial: origens do federalismo no Brasil. São Paulo: Globo, 2005.

DOMINGUES, Angela. Quando os índios eram vassalos: colonização e relações de poder no norte do Brasil na segunda metade do século XVIII. Lisboa: Comissão Nacional para as comemorações dos descobrimentos portugueses, 2000.

FLORY, Thomas. El juez de paz y el jurado en el Brasil imperial: control social y estabilidade política en el nuevo estado. México: Fondo de Cultura Economica, 1986.

FONSECA, Silvia. Federação e república na imprensa baiana (1831-36). In: LESSA, Mônica L.; FONSECA, Silvia C. P. de B. Entre a monarquia e a república: imprensa, pensamento político e historiografia (1822-89). Rio de Janeiro: Eduerj, 2008.

FREIRE, Ribamar Bessa. Rio Babel: a história das línguas na Amazônia. Rio de Janeiro: Atlântica, 2004.

GUIMARÃES, L. M. P; PRADO, Maria E. (org.). O liberalismo no Brasil imperial: origens, conceitos e práticas. Rio de Janeiro, Renavam / Uerj, 2001.

HURLEY, Jorge. Traços cabanos: 13 de maio (1836-1936). Belém: Instituto Lauro Sodré, 1936.

LIMA, Ana Renata do Rosário de. Revoltas camponesas no vale do Acará. Pará (1822-40). Dissertação de mestrado. Belém: UFPA/Naea, 2002.

LIMA, Leandro Mahalem de. Rios vermelhos: Perspectivas e posições de sujeito em torno da noção de cabano na Amazônia em meados de 1835. Dissertação de mestrado. São Paulo: USP, 2008.

LYRA, A. Tavares de. O Senado do Império. Revista do IHGB. Rio de Janeiro: vol. $153,1928$.

MACHADO, André Roberto de A. A quebra da mola real das sociedades: a crise política do Antigo Regime português na província do Grão-Pará (1821-25). São Paulo: Hucitec / Fapesp, 2010.

MACHADO, André Roberto de A. Redesenhando caminhos: o papel dos representantes do Grão-Pará na primeira legislatura do Império do Brasil (1826-29). 
Almanack Braziliense, n. 10, 2009.

MELLO, Teixeira de. Ephemerides nacionaes. Rio de Janeiro: Tipografia da Gazeta de Notícias, 1881.

MONTEIRO, John. Entre o gabinete e o sertão: projetos civilizatórios, inclusão e exclusão dos índios no Brasil Imperial. In: Idem. Tupis, tapuias e historiadores: estudos de história indígena e indigenismo. Tese de livre docência. Campinas: Unicamp, 2001.

MOREIRA NETO, Carlos de Araújo. Índios da Amazônia: de maioria a minoria (1750-1850). Petrópolis: Vozes, 1988.

MUNIZ, Palma. Adesão do Grão-Pará à independência e outros ensaios. Belém: Conselho Estadual de Cultura, 1973.

NABUCO. Joaquim Nabuco. Um estadista do Império. São Paulo: Instituto Progresso Editorial, s. d.

NOGUEIRA, Otaciano; FIRMO, João Sereno. Parlamentares do Império. Brasília: Senado Federal, 1973.

NOGUEIRA, Shirley Maria Silva. Razões para desertar: institucionalização do exército no Estado do Grão-Pará no último quartel do século XVIII. Dissertação de mestrado. Belém: Naea / UFPA, 2000.

OLIVEIRA, José Joaquim Machado de Oliveira. Juizo sobre as obras intituladas Corographia paraense ou descrição physica, histórica e política da província do Grão-Pará, por Ignácio Accioli de Cerqueira e Silva e Ensaio corographico sobre a província do Pará, por Antonio Ladislau Monteiro Baena. Rio de Janeiro: Tipografia Imparcial de F. de P. Brito, 1843.

PAOLO, Pasquale di. Cabanagem: a revolução popular na Amazônia. Belém: Cejup, 1986.

PEREIRA, Vantuil. Ao soberano Congresso: petições, requerimentos, representações e queixas à Câmara dos Deputados e ao Senado. Os direitos do cidadão na formação do Estado imperial brasileiro (1822-31). Tese de doutorado. Niterói: UFF, 2008.

PINHEIRO, Luís Balkar Sá Peixoto. Nos subterrâneos da revolta: trajetórias, lutas e tensões na Cabanagem. Tese de doutorado. São Paulo: PUC, 1998.

PRADO JR., Caio. Formação do Brasil contemporâneo (Colônia). São Paulo: Brasiliense, 1972.

RAIOL, Domingos Antonio. Motins políticos ou história dos principais acontecimentos políticos da província do Pará desde o ano de 1821 até 1835. Belém: UFPA, 1970.

REIS, Arthur Cezar. A autonomia do Amazonas. Manaus: Governo do Estado do Amazonas, 1965.

RICCI, Magda. Do sentido aos significados da Cabanagem: percursos historiográficos. Anais do Arquivo Público do Pará. Belém: s. i., 2001. 
RICCI, Magda. Um morto, muitas mortes. A imolação de Lobo de Souza e as narrativas da eclosão cabana. In: NEVES, Fernando Arthur de Freitas; LIMA, Maria Roseane Pinto (org.). Faces da história da Amazônia. Belém: Pakatatu, 2006.

RODRIGUES, José Honório. A Assembleia Constituinte de 1823. Petrópolis: Vozes, 1974.

SACRAMENTO BLAKE. Diccionário bibliographico brasileiro. Rio de Janeiro: Imprensa Nacional, 1937.

SALLES, Vicente. Memorial da Cabanagem. Belém: Cejup, 1992.

SALLES, Vicente. O negro no Pará, sob o regime da escravidão. Belém: UFPA, 1971.

SAMPAIO, Patrícia Maria de Melo. Espelhos partidos: etnia, legislação e desigualdade na colônia. Sertões do Pará, 1755-1823. Tese de doutorado. Niterói: UFF, 2001.

SAMPAIO, Patrícia Maria de Melo. Política indigenista no Brasil Imperial. In: GRINBERG, Keila; SALLES, Ricardo. História do Brasil imperial. 3 volumes. Rio de Janeiro: Civilização Brasileira, 2010.

SILVA, Ignácio Accioli de Cerqueira e. Corografia paraense ou descrição fisica, histórica e política da província do Grão-Pará. Salvador: Typografia do Diário, 1833.

SILVA, Innocêncio F. da. Dicionário bibliográfico português. Estudos de Innocêncio F. da Silva applicáveis a Portugal e Brasil. Continuados e ampliados por P. V. Brito Aranha. Revisto por Gomes de Brito e Álvaro Neves. Lisboa: Imprensa Nacional, 1858-1923. 23 volumes (versão eletrônica).

SILVA, João Nei Eduardo. Batista Campos: uma discussão biográfica na historiografia paraense. In: BEZERRA NETO, José Maia; GUSMÁN, Décio de Alencar (org.). Terra matura: Historiografia \& história social na Amazônia. Belém: Paka-tatu, 2002.

SLEMIAN, Andréa. Sob o império das leis: Constituição e unidade nacional na formação do Brasil (1823-34). São Paulo: Hucitec / Fapesp, 2009.

SOUZA FILHO, Argemiro Ribeiro de. Confrontos políticos e redes de sociabilidade: da crise do Antigo Regime à formação do Estado Nacional - Bahia. Relatório de qualificação do doutorado. São Paulo: USP, 2009.

SOUZA JR., José Alves de. Constituição ou revolução: os projetos políticos para a emancipação do Grão-Pará e a atuação política de Filipe Patroni (1820-23). Dissertação de mestrado. Campinas: Unicamp, 1997.

SOUZA, Otávio Tarquínio de. Evaristo da Veiga. São Paulo: Cia Editora Nacional, 1939.

SPOSITO, Fernanda. Nem cidadãos, nem brasileiros: indígenas na formação do Estado nacional brasileiro e conflitos na província de São Paulo (1822-1845). Dissertação de mestrado. São Paulo: USP, 2006.

VERNET, Augustin. Sociedades políticas da província de São Paulo na primeira metade do período regencial. Tese de doutorado. São Paulo: USP, 1975.

Recebido: 13/07/2009 - Aprovado: 22/12/2010. 
